\title{
Inherited or Earned? Performance of Foreign Banks in Central and Eastern Europe
}

\author{
Olena Havrylchyk and Emilia Jurzyk
}





\title{
IMF Working Paper
}

Strategy, Policy, and Review Department

\section{Inherited or Earned? Performance of Foreign Banks in Central and Eastern Europe ${ }^{1}$}

\section{Prepared by Olena Havrylchyk and Emilia Jurzyk}

Authorized for distribution by Lorenzo Giorgianni

January 2010

\begin{abstract}
This Working Paper should not be reported as representing the views of the IMF. The views expressed in this Working Paper are those of the author(s) and do not necessarily represent those of the IMF or IMF policy. Working Papers describe research in progress by the author(s) and are published to elicit comments and to further debate.

Using a combination of propensity score matching and difference-in-difference techniques we investigate the impact of foreign bank ownership on the performance and market power of acquired banks operating in Central and Eastern Europe. This approach allows us to control for selection bias as larger but less profitable banks were more likely to be acquired by foreign investors. We show that during three years after the takeover, banks have become more profitable due to cost minimization and better risk management. They have additionally gained market share, because they passed their lower cost of funds to borrowers in terms of lower lending rates. Previous studies failed to pick up the improvements in performance of takeover banks, because they did not account for the performance of financial institutions before acquisitions.

JEL Classification Numbers: G15, G21, G34, F36

Keywords: foreign banks, foreign acquisition, propensity score matching Author's E-Mail Address: olena.havrylchyk@cepii.fr, ejurzyk@imf.org,

\footnotetext{
${ }^{1}$ We would like to thank Agnès Bénassy-Quéré, Paul DeGrauwe, Hans Degryse, Steven Ongena, Damiaan Persyn, Patrick Van Cayseele, and Rudi Vander Vennet as well as participants of FIRS 2009 conference and seminars at the IMF and CEPII for helpful comments and suggestions. Emilia Jurzyk gratefully acknowledges financial support from the Research Council of the KU Leuven, in the framework of Central and Eastern European Initiatives.
} 


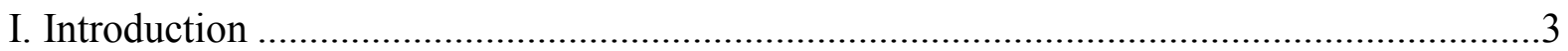

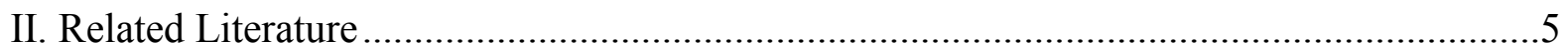

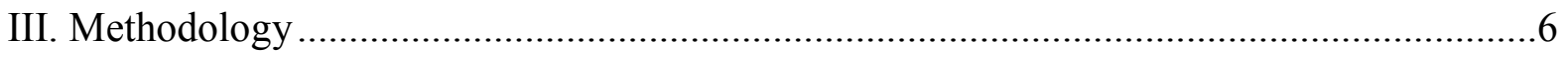

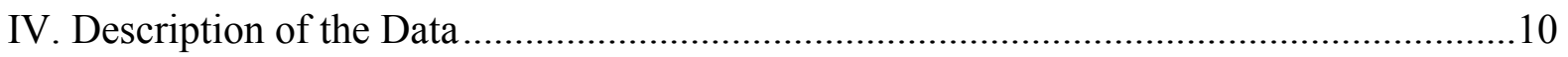

V. Descriptive Statistics and Evidence of the Selection Bias ..........................................11

VI. Propensity Score Matching to Control for the Selection Bias .........................................12

VII. Results From the Difference-in-Difference Analysis on the Matched Sample..............15

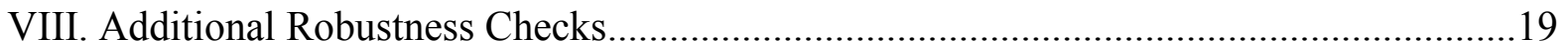

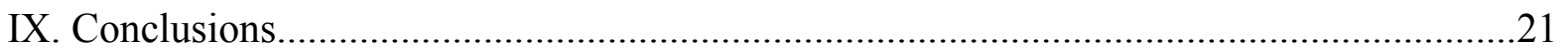

Tables

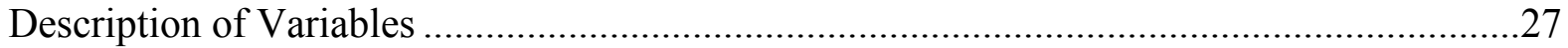

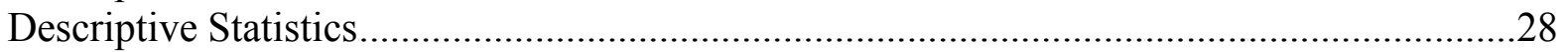

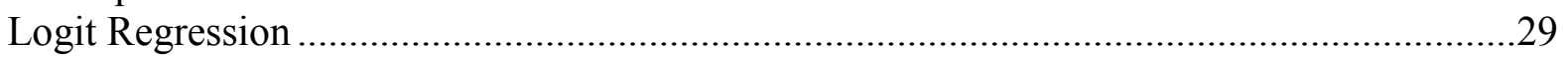

Results of the matching procedure for ROA and Market Share ..........................................30

Results of the matching procedure for ROA and Market Share_-Same Sample ...................31

Results of the Matching Procedure - Decomposition of ROA and Size ...............................32

Results of the Matching Procedure - Sample Restricted to Two and Three ..........................33

Results of the Matching Procedure for ROA and Market.....................................................34

Results of the Matching Procedure for ROA and Market Share. .........................................35

Figures

ROA Trajectories for Takeover, Greenfield, and Domestic Banks ....................................36

Market Share Trajectories for Takeover, Greenfield, and Domestic Banks..........................36

Appendix

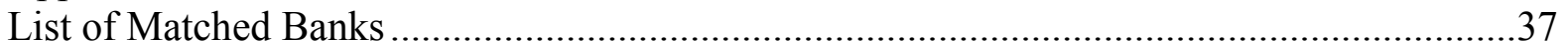

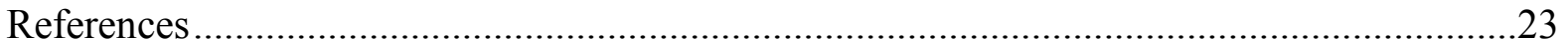




\section{INTRODUCTION}

Foreign acquisitions of banks since the 1990s have substantially altered the financial landscape and governance of banks in many transition and developing countries. As of end 2008, foreign banks accounted for more than 39 percent of total banking assets in developing countries. Their presence is particularly important in Central and Eastern Europe, Latin America, and Sub-Saharan Africa where more than 50 percent of local banking markets are controlled by foreign investors. Such a transformation has given rise to a large literature that analyzes the impact of foreign bank ownership and mode of entry on banks' performance, measured by X-efficiency, net interest margin, lending rates, profitability, profit-efficiency, and loan growth. However, there is a striking lack of studies that look at the qualities of banks that were acquired by foreign investors. This is particularly surprising because if foreign banks acquire institutions in developing countries that possess certain characteristics, the standard results of post-acquisition performance are biased.

The hypothesis that selection bias exists - as only banks with certain characteristics was taken over - is supported by evidence, but the direction of this bias often depends on the region. In general, we can plausibly assume that foreign investor would prefer to acquire more profitable and healthier banks with high market power. Moreover, some authorities preferred to recapitalize and clean up portfolios of target banks in order to make them more attractive for foreign investors, which was the case of partial bank privatization in China. On the other hand, in many countries the authorities were skeptical towards foreign investors and allowed foreign acquisition of only failing institutions, like in Poland. Very often entry barriers were loosened only in the wake of crises and this was motivated by the need to recapitalize and reestablish a functioning banking system. This was the case of Baltic and Balkan countries after the Russian crisis, Argentina after Mexico's tequila crisis, and many East Asian countries following their 1997-98 financial crises.

The existence of a selection bias has crucial implications for the analysis of post-acquisition performance of financial institutions. For instance, if foreign banks acquire institutions with deteriorating financial stance-like it happened in most of the Central and Eastern Europethe standard regression methods of analyzing the post-takeover performance would result in downward-biased estimates. This, in turn, would explain a consistent lack of empirical evidence on the benefits of foreign acquisition in developing countries. Existing studies demonstrate that foreign banks are more efficient and profitable than domestic institutions, and they experience faster and more stable loan growth (Bonin and others, 2005; Haas and Lelyveld, 2006). A closer examination reveals, though, that the mode of foreign bank entry plays an important role, as we only observe superior performance of institutions that have been newly established. At the same time, there is no evidence that the performance of banks that were acquired by foreign investors is superior to domestic ones (Havrylchyk and Jurzyk, 2007). Without this proof, the results obtained for greenfield institutions cannot be entirely attributed to benefits of foreign ownership but rather raise suspicion that they merely reflect a 
different borrower mix, with a higher share of large and transparent clients at the expense of small and medium enterprises.

In the present paper we propose to use a combination of propensity score matching and difference-in-difference (DID) techniques to analyze the issues raised above. This is a new methodology in the area of bank performance research, which is borrowed from other fields of economics, namely labor and firm performance. Recently, matching methods have also been used in financial studies, both in the analysis of firm- (Giannetti and Ongena, 2008; Ioannidou and Ongena, 2008), and bank-level data (Drucker and Puri, 2005). We believe, however, that our study is the first one to apply it to the examination of bank mergers.

The main purpose of our analysis is to compare banks that were acquired by foreign investors with comparable domestic banks that have stayed in domestic ownership during the analyzed period. In order to determine "comparable" banks we use propensity score matching, which implies running a logistic regression, where a probability of a bank being acquired is a function of observable bank and country characteristics. This allows us to assign to each bank a probability of being acquired and then to match foreign banks with domestic banks that are the "closest" in terms of the propensity score. In the second step, we compare the performance of acquired bank with the matched domestic bank. To do so we rely on difference-in-difference technique as it allows us to take into account non-observable preacquisition differences that we were not able to control for in the first step. We apply this methodology to a dataset comprising 352 banks from 11 Central and Eastern European countries (CEECs) between 1993 and 2006. Since this region recorded the highest inflow of foreign direct investment into the banking system in the world and we were able to identify 77 cross-border acquisitions, we believe it presents an excellent laboratory to perform such a study.

In our analysis of post-acquisition behavior of banks, we focus on the possible trade-off between performance and market power of banks. This is an important issue, because foreign bank ownership has gone hand in hand with higher market concentration. Moreover, foreign banks have contributed to this development directly by acquiring and merging domestic institutions, or by motivating smaller domestic banks to merge in the face of increased competition (Martinez Peria and Mody, 2004; Lanine and Vander Vennet, 2007). If banks with large market power can set prices that are less favorable to consumers and earn abnormal profits, this should raise concerns about the competition on the market (relativemarket-power hypothesis of Shepherd (1982)). Alternatively, if higher market power of foreign banks results from their superior performance and acquisition of less efficient banks, this should be welcomed by the supervisors (the efficient-structure hypothesis of Demsetz (1973)).

We believe that our paper is the first one that rigorously treats the effects of selection bias during foreign bank acquisitions on the post-acquisition performance. Our empirical strategy 
yields a number of interesting results. We show that foreign investors did not acquire banks at random, but chose institutions with large market power. Moreover, the acquired banks were often in poor financial condition, as measured by the return on assets (ROA). Controlling for this selection bias, we find a positive impact of foreign bank ownership on acquired banks' performance, as well as on their market power. We show that during three years after the takeover, banks have become more profitable due to cost minimization and better risk management. They have additionally gained market share, because they passed their lower cost of funds to borrowers in terms of lower lending rates. Our methodology offers us also a unique possibility to track the dynamics of banks' post-acquisition performance. We show that while the changes in profitability appear one year after the acquisition, market share increases only after two years. In total, the results of our analysis lead us to believe that previous studies failed to pick up these improvements in banks' performance because they assumed that acquisitions were done randomly.

The paper is structured as follows. In Section 2 we shortly review the relevant literature. Section 3 describes methodology and Section 4 presents our dataset and Section 5 computes descriptive statistics. Section 6 analyzes the results of the propensity score matching model and Section 7 includes findings about the effect of foreign ownership using difference-indifference technique. In Section 8 we report additional robustness checks and Section 9 concludes.

\section{RELATED Literature}

The literature on the effects of cross-border bank mergers usually analyzes only the static outcomes and, therefore, picks up only the long-run performance effects. The method most accepted in the empirical literature is to introduce a dummy variable that takes the value of one for a bank after it has been acquired by a foreign institution and zero otherwise. However, such an approach may fail to pick up any significant changes in the postacquisition performance of banks. There are few plausible explanations for this. First of all, foreign investors might have targeted domestic banks with certain characteristics, like higher profits or bigger market share. Second, banks that chose to enter via takeovers were usually facing administrative entry barriers which often loosened in the wake of the crises. Thus, they operated in less favorable conditions during their first few years of existence. Finally, earlier studies do not look at the possible transition period that follows the takeover. It could take a few years for a bank to be reformed and initially we might even observe, for example, an increase of costs as the bank is spending more on training of its employees and investing in modern technology.

One of the earliest attempts to address the issue of selection bias is done in the work of Peek and Others (1999) that focuses on the period around the time of ownership changes in the United States. They try to determine whether poor performance of foreign banks is the result of changes in business strategy or the preexisting characteristics of target banks. Their 
findings indicate that target banks of foreign acquirers exhibit lower profitability prior to the acquisition, during the transition period, and in the long run after the change of ownership.

Berger and others. (2005) differentiate explicitly between static, selection and dynamic effect of foreign ownership using data on Argentinean banking sector. They investigate the impact of these effects on five variables: (i) profit efficiency rank; (ii) ROE; (iii) cost efficiency rank; (iv) cost-to-asset ratio; and (v) the ratio of nonperforming loans. Their data suggests that foreign ownership is associated with lower profit efficiency than domestic ownership (static effect), that acquired banks did not differ significantly from the banks that have remained domestic except for slightly higher costs (selection effect), and that there was little improvement in the performance of banks after the acquisition (dynamic effect).

By focusing on the trade-off between performance and market power, the paper is also related to the extensive literature that analyzes the relationship between market structure and performance of banks. According to the structure-conduct-performance hypothesis, higher market concentration leads to imperfect competition. This allows banks to set prices that are less favorable to consumers and results in higher bank profits (see Berge and others, 1999, for a survey). A similar hypothesis of relative market power asserts that only firms with large market power and well-differentiated products are able to exercise market power in pricing these products and earn abnormal profits. Additionally, it is hypothesized that managers of large firms could make less effort to maximize efficiency - the so called "quiet life" effect (Berger and Hannan, 1998). An alternative explanation of the positive relationship between high concentration and profitability is offered by Demsetz (1973). She formulates the efficient-structure hypothesis, which suggests that more efficient banks, which are also more profitable, gain large market shares, which may result in high levels of market concentration. $^{2}$

We contribute to the above literature by estimating the impact of foreign ownership on performance and market power of acquired institutions by using a new methodology, which allows us to overcome the selection bias. The methodology is described in detail in the following section.

\section{Methodology}

The aim of our analysis is to estimate the causal effect of foreign ownership on bank performance. To do this we use a method that is based on matched sampling (Heckman and others., 1997; Heckman and others., 1998). This approach is mainly used in labor economics,

\footnotetext{
${ }^{2}$ Berger (1995) attempts to distinguish between the structure-conduct-performance, relative-market-power and efficient-structure hypotheses and, even thought he finds that the superior X-efficiency is associated with higher profits, he does not find proof that this leads to higher concentration of the market. His results provide support for the relative-market-power hypothesis but run contrary to the structure-conduct-performance paradigm.
} 
but has also been successfully incorporated into studies that analyze causality between exports and productivity of firms (De Loecker, 2007), as well as an impact of foreign direct investment on performance of firms (Arnold and Javorcik, 2005). More recently, this method was used in finance to analyze both firm- (Giannetti and Ongena, 2008, Ioannidou and Ongena, 2008), and bank-level data (Drucker and Puri, 2005). We believe that we are the first to apply this method to the analysis of post-acquisition bank performance.

Our empirical estimation proceeds as follows. As a first step, we use propensity score method and estimate probability that a domestic bank is taken over in a given year by a foreign bank. This probability is subsequently used to match each takeover bank to a bank that remained in domestic hands. Since we match each foreign bank to a domestic bank with a similar set of observable characteristics in the year preceding the takeover, we limit, if not eliminate, the selection bias. Next, to assess the impact of foreign acquisitions, we use difference-indifference approach and compare the performance of takeover banks with the matched domestic banks. We concentrate on the changes in performance that take place within the same bank after the takeover in comparison to the matched bank. While this limits the number of observations that we are able to use in our analysis, it allows us to draw conclusions regarding the causal effect of foreign acquisition, as well as to account for all time-persistent non-random elements of the acquisition decision.

Here we present a more formal outline of the chosen procedure. First, we define a treatment indicator $\mathrm{T}_{\mathrm{it}}$ that equals one if bank $i$ is taken over by a foreign investor in year $t$ and zero otherwise. The potential outcomes are then defined as $\mathrm{Y}_{\mathrm{i}}\left(\mathrm{T}_{\mathrm{i}}\right)$ for each bank $i$, where $i=1, \ldots$, $N$ and $N$ denotes the total population. Hence, the causal effect of foreign acquisition on bank performance ( $\tau_{A T T}$, the Average Treatment of the Treated, ATT) can be defined as:

$$
\tau_{A T T}=E(\tau \mid T=1)=E(Y(1)-Y(0) \mid T=1)=E[Y(1) \mid T=1]-E[Y(0) \mid T=1]
$$

Which is the difference between the performance of a bank that was acquired by a foreign investor $(E[Y(1) \mid T=1]$ ) and the analogous outcome of the same bank had it not been acquired $(E[Y(0) \mid T=1])$. The latter outcome - $E[Y(0) \mid T=1]$ - is a counterfactual that is not observed, and therefore one has to select a proper substitute for it in order to estimate ATT. Using the mean outcome of banks that have remained domestic $E[Y(0) \mid T=0]$ is not a good choice, because it is most likely that factors which determine the acquisition decision also determine the post-acquisition performance. One method to resolve this selection problem is to construct a counterfactual using propensity score matching. This technique relies on estimating the probability of a bank being acquired by foreign investors given an observed set of bank characteristics X (Rosenbaum and Rubin 1983a, 1983b and 1984), and then matching taken-over banks with domestic banks with values of probabilities that are close to the taken-over banks. Naturally, the validity of this technique relies on two assumptions: 
(i) that takeover decision is based on the set of observables included in the estimation;

(ii) that banks with similar probabilities would evolve in a similar manner. Hence, the performance of an acquired bank can be written as:

$$
\begin{aligned}
E[Y(1)-Y(0) \mid T=1]= & \{E[Y(1) \mid T=1, X)-E[Y(0) \mid T=0, X]\} \\
& -E\{[Y(0) \mid T=1, X)-E[Y(0) \mid T=0, X]\}
\end{aligned}
$$

The second term in Equation (2) denotes the difference between the performance of an acquired bank had it not been acquired, and a domestic bank. This selection bias is assumed to be zero, conditional on the set of observable characteristics that determine the takeover decision $\mathrm{X}$. In this case, the remaining difference between acquired banks and matched domestic banks represents the causal effect of foreign ownership, and can be estimated using the available data.

To perform the propensity score matching technique, we first estimate the logit regression where we model the probability of being acquired by foreign investor on the basis of bank specific and country specific characteristics:

$T_{i t}=\left\{\begin{array}{l}1 \text { if } \beta X_{i t-1}+\varepsilon_{i t}>0 \\ 0 \quad \text { otherwise }\end{array}\right.$

Where $T_{i t}$ - is the treatment indicator defined above, $X_{i t-1}$ - is a vector of factors that determine the probability of a bank of being acquired by foreign investors. It is important to stress that we want to capture the probability of being acquired, and not the probability of being foreign-owned. This is the reason why $T_{i t}$ is equal to 1 only in the year of acquisition, and not for all years when bank is in foreign ownership. Consequently, in the logit regression observations after the year of acquisition are dropped. Greenfield banks, as well as banks that were foreign throughout our sample are excluded since they are foreign-owned the whole time, and we cannot investigate the probability of them being acquired.

Based on equation (3) we assign the propensity score, i.e. the probability of being acquired, to each bank. At this stage it is important to ensure that the balancing hypothesis is satisfied. The latter states that for a given propensity score, exposure to treatment is random, and therefore treated and control banks should be on average observationally identical. In practice, we split the sample into equally spaced intervals in which the average propensity score of treated and control banks does not differ and, within each interval, we test whether the mean of every variable of $X$ is the same in the treated and control groups. In this way we match on the probability to be acquired by foreign investors controlling for characteristics captured by X. 
Now we can match each foreign bank with a domestic bank that has the closest propensity score, but has never been acquired. There are several algorithms to do so, and we rely on the most commonly used in the literature, namely Nearest Neighbor Matching. We match each acquired bank with a bank that remained domestic and is the closest in terms of propensity score value to the acquired bank. ${ }^{3}$

Finally, once we have matched foreign banks with similar domestic banks, we are able to use difference-in-difference approach. That means that we calculate the ATT presented in equation 2 and subtract from it the difference in performance between acquired bank and a matched bank one year before the takeover:

$$
A T T_{0+t}=\frac{1}{N} \sum_{i=1}^{N}\left(\text { Bank }_{i, 0+t}^{\text {foreign }}-\text { Bank }_{i, 0+t}^{\text {control }}\right)-\frac{1}{N}\left(\sum_{i=1}^{N}\left(\text { Bank }_{i,-1}^{\text {foreign }}-\text { Bank }_{i,-1}^{\text {control }}\right)\right),
$$

where Bank $^{\text {foreign }}$ and Bank ${ }^{\text {control }}$ is a bank characteristic of interest for the foreign and control bank, respectively. The year of acquisition is defined as year 0 . Since the impact of foreign acquisition on the acquired bank probably does not manifest immediately, we additionally calculate ATT for 1, 2, and 3 years after the acquisition.

A more common procedure to estimate ATT is just to use first half of the formula (4) which computes the difference between foreign banks and the control group. This would be correct if we believed that the selection was based only on observable bank characteristics. Combining matching with difference-in-difference approach allows some scope for unobserved determinants as long as they can be represented by separable individual-and/or time-specific components of the error term. In this case, we look at the before-after evolution instead of levels, and if there were some unobservable characteristic that led to banks being acquired, we can control for their evolution as well (Blundell \& Costa Dias, 2000).

The ATT presented in formula (4) shows the effect of takeover on bank performance after 1, 2 , or 3 years per year. In order to analyze whether these effects persist over time, we additionally compute cumulative ATT, which shows the effect of takeover from zero up to the 1 st, 2 nd or 3 rd year after takeover:

$$
A T T_{c, 0+t}=\sum_{t=1}^{J}\left[\frac{1}{N} \sum_{i=1}^{N}\left(\text { Bank }_{i, 0+t}^{\text {foreign }}-\text { Bank }_{i, 0+t}^{\text {control }}\right)-\frac{1}{N} \sum_{i=1}^{N}\left(\text { Bank }_{i,-1}^{\text {foreign }}-\text { Bank }_{i,-1}^{\text {control }}\right)\right]
$$

\footnotetext{
${ }^{3}$ One can argue that if the distance between a foreign bank and its matched counterpart is very large, this matching is not useful. To address this issue, we tried to limit the search for the nearest neighbor to $25,50,100$ closest observations, but the final results were not influenced by this exercise.
} 
Where $\mathrm{t}$ stands for the period and $\mathrm{J}=1,2,3$.

Testing the statistical significance of ATT is not straightforward because the estimated variance of the treatment effect should also include variance arising due to the estimation of the propensity score. To circumvent this problem, we use bootstrapped standard errors. We set the number of bootstrap replications to 1000 .

The main disadvantage of our chosen methodology is the need of a large dataset that has bank information for at least two consecutive years. This should apply to acquired banks, as well as to domestic banks which are matched with them. We have identified 73 foreign acquisitions that satisfy these criteria, but the number of analyzed transactions decreases to 54 when we analyze the impact after three years of foreign ownership. ${ }^{4}$ The lack of large database also prevents us from constructing more data demanding measures of performance, such as X-efficiency or profit-efficiency. Therefore, we focus on more simple accounting measures, such as ROA and market share.

\section{Description OF THE DATa}

All bank-specific information used in this study comes from Bureau Van Dijk's BankScope database. We extract from it information on banks operating in 11 countries in Central and Eastern Europe (Bulgaria, Croatia, the Czech Republic, Estonia, Hungary, Latvia, Lithuania, Poland, Romania, Slovakia, and Slovenia) between 1993 and 2006. As a result, our panel contains balance sheet and income statement figures on 352 commercial and saving banks in CEECs. We exclude investment banks, micro-finance banks and development banks. For all these banks we use unconsolidated statements whenever possible, relying on consolidated statements otherwise. The data on macroeconomic variables is taken from the International Financial Statistics of the IMF, and the indicators of the competition in CEECs from the EBRD Transition reports. The definitions of variables and all data sources are given in Table 1.

Appropriate information on bank ownership is crucial to our analysis. As the BankScope database lacks historical ownership data, for the years 1994-2001 we use information kindly provided by Haas and Lelyveld (2006). For the remaining years we determine the ownership changes ourselves, on the basis of banks' official publications and central bank reports. We categorize a bank as foreign in a given year if at least 51 percent of its capital was owned by foreign investors. Due to the ongoing privatization process in CEECs there is a need to

\footnotetext{
${ }^{4}$ We have also tried to delete banks that do not have enough consecutive observations before performing the matching. This gives us a higher number of observations, but this also leads to the bias, since we delete worse performing banks, which are more likely to provide worse data. Our final results were not influenced by this.
} 
account for the state bank ownership. Therefore, we construct a dummy state-owned, based on the information that was made available to us by local banking supervisory authorities. ${ }^{5}$ After combining the dataset, we aggregate the data for banks that merged in the course of the period analyzed in our study. We do this to ensure that we capture the effect of foreign ownership and not the effect of domestic mergers and acquisitions.

\section{Descriptive Statistics And Evidence of the Selection Bias}

Table 2 presents descriptive statistics for the following bank characteristics: return on assets (ROA), net interest margin (NIM), Capital, Costs, Interest Income, Interest Expenses, Size, Market Share, Loan Loss Provisions (LLP). We present mean and standard deviation for the above variables for banks that have remained domestic during the analyzed sample (Domestic), and for banks that have been taken over (Takeover). It should be mentioned, that Takeover represents the statistic for all observations available for a takeover bank, both before and after the acquisition. Then we calculate the statistics separately for the period before (Before) and after the takeover (After). The columns A, B, and C show the results of $\mathrm{t}$-statistic tests for the difference in means between takeover and domestic banks (column A), takeover banks before, takeover banks after the takeover and domestic banks (column B), and between takeover bank before and after the takeover (column C).

Our descriptive statistics show that banks that became targets of foreign acquisitions significantly differed from other domestic banks. First, acquisition targets held almost 25 percent less equity in relation to total assets that domestic banks, and incurred total costs lower by almost 23 percent. The most striking difference can be seen in the comparison of market shares, however. Acquired banks controlled on average over twice as high a market share than banks that remained domestic during the analyzed period. If we assume that large banks as a rule have lower costs due to economies of scale and can afford to hold less capital, we can conclude that foreign investors primarily picked large banks as their targets in order to gain market power.

Next, to see whether the performance of target banks changed after the acquisition we compare the performance of banks before and after takeover. The results of t-tests are presented in column $\mathrm{C}$. This basic statistics suggest that foreign owners were not able to maintain high market share of acquired institutions: market share dropped by almost 26 percent with respect to pre-takeover levels. At the same time, the average size of takeover

\footnotetext{
${ }^{5}$ We are particularly grateful to Nikolay Nenovsky and Lyubomir Mirchev (Bulgarian National Bank), Maire Otsus (The Financial Supervision Authority of the Bank of Estonia), Dobromil Serwa and Sylwester Kozak (National Bank of Poland), Florian Neagu (National Bank of Romania), Evan Kraft (Croatian National Bank), Elmars Zakulis (National Bank of Latvia), Róbert Szegedi (National Bank of Hungary), Loreta Sprindziunaite (National Bank of Lithuania), Tomas Rydl (Czech National Bank), and Hendrich Datel (National Bank of Slovakia) for providing us information on state ownership of banks.
} 
bank increased by 3.5 percent. These seemingly contradictory results can be explained by the increasing presence of greenfield banks and the possible change in strategies of domestic banks. While new owners of acquired banks compete for clients with greenfield banks, they find themselves at a disadvantage because they are burdened by inherited nonperforming loans. In contrast, greenfield banks start their operations from scratch and can grow faster by offering lower interest rates to attract clients. Moreover, better macroeconomic conditions and improving credit assessment skills of employees might have encouraged remaining domestic banks to start granting more loans. As a result, while foreign banks increased in size, they lost substantial part of their market share. In order to counteract this loss, banks seemed to have decreased their interest margins, as manifested in NIM that declined by 16 percent.

To better visualize the presence of the selection bias, we plot the evolution of ROA and market share over time for takeover banks on Figures 1-2. We also plot the average performance of greenfield banks. The period 0 refers to the date of acquisition for takeover banks and the date of establishment for the greenfield banks. We compare performance of these banks with the average performance of banks that have always stayed in domestic ownership. We restrict our analysis only to three years around the date of bank acquisition or establishment due to the data availability constraints. We find that both profitability and market share of the acquired banks were decreasing before acquisition and grew afterwards, which is in line with the evidence that many banks were acquired in the wake of the crises or when they experienced financial difficulties. It is interesting to note that the trajectory of ROA seems to be much more dramatic than the one for the market share, even though the t-statistic fails to show the difference in the pre- and post-acquisition performance. Hence, these figures can be additionally interpreted as showing the importance of controlling for the transition period after the takeover in order to understand the time requirements of new investors to reform an acquired bank.

\section{Propensity Score Matching to Control for the Selection Bias}

In order to analyze the effect of takeover on the performance of banks operating in CEECs, we next turn to the propensity score and DID methodology. To estimate propensity scores, we rely on the logit regression (3), where the dependent variable is equal to 1 for the year of acquisition and 0 otherwise. We select our conditioning variables to control for factors that are expected to affect both the acquisition decision and the performance after the acquisition or proxy for the unobservable that play a role in both dimensions. In our choice of model specification we rely on the literature that analyzes the factors influencing entry decisions of foreign banks (Magri and others., 2005; Buch and DeLong, 2004) and flows of FDI into the financial and nonfinancial sector (Blandon, 2001; Buch, 2000a; Buch, 2000b; Wezel, 2004).

First of all, we control for bank-specific characteristics to see whether foreign investors chose particular targets when they make acquisition decisions. In particular, we investigate whether 
the entry decision was motivated by profitability and financial health concerns or rather by the market power of domestic banks. To this end, we include bank profitability (measured by ROA), capitalization (CAP) and bank size. ${ }^{6}$ In addition we control for state ownership of banks since public institutions are not always motivated by profitability or efficiency concerns, but might exercise development functions, like extending loss making loans to subsidize "social projects" (La Porta and others., 2002).

Second, we control for the "follower relationship hypothesis", which states that banks follow their customers from home countries, being afraid of losing them once they have established relationships with banks operating in foreign countries (Grubel, 1977). Hence, we include a ratio of non-financial foreign direct investment to GDP (FDI) to control for the degree of economic integration among countries. We expect it to have a positive effect on the probability of being acquired.

Third, we use a set of variables to investigate the role of local market profit opportunities in attracting foreign banks. Abundant evidence shows that foreign banks succeeded to capitalize on their comparative advantages in relatively poor countries with inefficient and uncompetitive banking sectors (Claessens and others., 2001). To control for this we include the real lending rate (Lending rate), which serve as a proxy for banking sector efficiency and for profit opportunities. High lending rates might signal inefficiency of local financial intermediation, which promises more profits for foreign banks if they take over domestic institution and cut costs (Wezel, 2004).

Next, we incorporate measures of host country market size. First, we include real GDP growth (GDP_GR) and the log of host country GDP per capita (GDPPC) into the logit regression. With these variables we hope to pick up the attractiveness of local markets (Buch and Lipponer, 2006, Yamori, 1998; Wezel, 2004) as well as the timing of takeovers. On the one hand, we can expect that most takeovers took place when local economies were growing fast and their future economic prospects looked promising. Alternatively, some countries allowed foreign bank entry only when they did not succeed to reform the banking sector. As a result, foreign banks entered after crisis periods and during low growth. Finally, we include EBRD index of competition reforms to control for the regulatory environment in which banks and firms operate (Lanine and Vander Vennet, 2007). One could argue that foreign banks only enter banking sectors that sufficiently protect property and creditor rights.

The results of the logit regressions are presented in Table 3. The descriptive power of the model is relatively high when compared to similar models. Before turning to the analysis of our results we should also note that the balancing hypothesis is satisfied. This means that the

\footnotetext{
${ }^{6}$ We experiment with this variable and use either bank Size or Market Share. The results are robust to the inclusion of either of the two variables; hence we present only the results with size.
} 
mean of every explanatory variable has to be the same for the treated and control group in every block. ${ }^{7}$ This ensures that observations with the same propensity score have the same distribution of observable characteristics independently of the treatment status (takeover or no takeover). In other words, for a given propensity score, exposure to treatment is random and therefore treated and control units should be on average observationally identical. The fact that balancing hypothesis is satisfied indicates that we control for the selection bias.

Our model of propensity of being acquired by foreign investors shows that there is an important selection bias when it comes to acquisition decisions. Foreign investors were attracted by targets that were large and well capitalized. Interestingly, acquired banks experienced on average lower profitability than their domestic peers, which reflected the situation when foreign investors were only allowed to acquire banks after crises and/or when banks experienced financial difficulties. All these bank-specific coefficients are economically relevant. An increase of half standard deviation in the size of a bank increases the probability of it being acquired by 1.4 percentage points, which is a significant amount taking into account that the average probability of a bank being acquired in a given year amounts to 4.1 percent. Similarly, a decrease of half standard deviation in ROA increases the probability of acquisition by 0.5 percentage points. Despite the belief that most foreign investors acquired banks during the privatization process, being owned by the state decreased the probability of acquisition by 1.1 percentage points. In fact, with the exception of a few large banks in each country, foreign banks mostly took over private institutions.

Among country characteristics, the important role was played by the ratio of foreign direct investment to GDP, which is consistent with the "follower relationship hypothesis". An increase in FDI by half standard deviation increases the probability of a bank from the FDIreceiving country being acquired by 1.3 percentage points. To illustrate, such an increase would correspond to Croatia increasing its volume of FDI inflows in relation to GDP in 2004 to the level of Hungary in 1993. The high real lending rate on the market showed its inefficiency, promised high future profits after the restructuring of the target bank, and also had a positive impact on probability of being acquired. Half standard deviation increase in real interest rate raised the probability of bank being acquired by 3 percentage points.

It is interesting to see that even though foreign banks preferred countries with underdeveloped banking sector, they were more likely to enter markets with more competitive environment for firms, as measured by the EBRD index. For example, in 1995 domestic banks in Poland had 6.8 percentage points higher probability of being acquired than banks in Lithuania. This can be interpreted as a sign that foreign banks were more likely to enter countries with good prospects for profits from lending, but with still uncompetitive financial markets. Furthermore, the fact that foreign banks chose to enter when economies

\footnotetext{
${ }^{7}$ The results of this exercise are available upon request.
} 
were still poor (as measured by GDP per capita) and growing slowly (overall country GDP) is probably due to lower price of target banks. The negative impact of GDP growth is also consistent with the observation that foreign bank entry was often allowed only in the wake of the crises when local authorities experienced financial difficulties.

Our results are broadly in line with the existing literature that analyzes factors that influence the decision of foreign banks to enter new markets. However, we should note that in most of these papers the dependent variable is not constructed on a bank level, but country level. Magri and others. (2005) measure the number of foreign banks by country of origin as a share of the total number of banks operating in Italy. Buch and DeLong (2004) analyze the number of mergers between banks from different countries, whereas Buch (2000) looks at the amount of foreign direct investment from Germany into banking sectors of different countries. Our results are directly comparable to finding of Lanine and Vander Vennet (2007) who find that, among bank characteristics, the size is the most important bank characteristic that explains the acquisition decisions of foreign investors in CEECs.

\section{ReSUlts From THE DifFERENCE-IN-DifFERENCE ANALysis ON THE MATCHED SAMPle}

Once we have computed propensity scores based on the model discussed in Section 6, we can proceed with our difference-in-difference analysis. As it was already mentioned in Section 3, we compute ATT following the formula (4), and the cumulative ATT using the formula (5). We additionally impose an important assumption and match foreign banks with domestic banks that have the closest propensity score but only in the same year. 8 We rely on such subpopulation matching, because there were massive economic reforms throughout the analyzed period in CEECs which have changed the performance of many banks. Therefore, if we do not control for time, we risk matching the performance of a foreign bank in the post reform period with the performance of a domestic bank prior to these changes. Even though we control for many macroeconomic and structural changes in our logit regressions, the differences could still remain and the safest way to avoid mistakes is to match banks separately within each year. Moreover, if a foreign investor becomes interested in acquiring a bank, it compares it with other institutions available for purchase in the same period. It is important to note that we only match banks that fall on common support. The list of matches is presented in Appendix and the results of difference-in-difference analysis are presented in Tables 4 to 9 .

In Table 4, we present our results for the two main variables of interest; namely ROA and market share. To capture the transition period, we present ATT for the acquisition year and

\footnotetext{
${ }^{8}$ Due to the data constraints we are not able to match banks per year and country.
} 
one, two and three years after the takeover (panel A), and the cumulative results after one, two and three years (panel B).

Our findings show that foreign acquisition has no impact on the bank in the year of the acquisition, but starting from the first year, there is a sustained increase in profits relative to domestic banks that are in the control group. Two years after the acquisition, market share of the acquired banks starts to increase as well. We find that after three years foreign investors succeed to increase profitability of an average acquired bank by 1.7 percentage points and to gain additionally 2.3 percentage points of the market share. This is an economically significant result, especially when we take into account that average ROA for banks that remained in domestic hands was 0.38 percent and average market share for the same institutions was 10.25 percent. While the result for market share might seem contradictory to the descriptive statistics (as can be seen in Table 2, market share of takeover banks decreases with respect to the pre-takeover value), it is important to remember that here we compare the takeover banks to the matched domestic institutions. Our results are robust if we look at the cumulative effects (panel B). The increases in both ROA and market share are not a one-time phenomenon and persist over time.

As we do not observe a very high number of mergers in CEECs, we decided to use all observations for every year after the takeover. This implies, however, that we do not analyze the same banks each year. In order to make sure that our results are not driven by a sample bias, we perform the same exercise restricting the number of banks to those on which we have data for two consecutive years after the acquisition. Next, we restrict the sample to banks for which we have observations for three consecutive years. The results on the same sample are presented in Table 5 and support our previous findings. Bank profits start rising one year after the acquisition, while market share starts increasing in year 2. Actually, with the restricted samples the results for ROA are even higher than with all observations included, while the results for market share remain virtually the same.

Looking at the results in Tables 4 and 5, we do not find any evidence that foreign banks attempt to increase their market share at the expense of lower profits. It rather seems that good performance of foreign banks makes them more attractive to clients, which in turn increases their market share. This is in line with "efficiency" hypothesis and, therefore the increased concentration of the market reflects a more competitive banking industry. This result is contrary to the evidence found for developed markets such as the U.S. and Australia by DeYoung and Nolle (1996), Williams (1998a), Williams (1998b), and Williams (2003). They argue that foreign banks did not succeed in tapping the pool of domestic depositors and therefore had to rely on expensive purchased funds, which decreased their profits. The situation in transition countries is different because by acquiring existing domestic institutions foreign banks already inherit the customer network and can benefit from it. Furthermore, foreign banks that enter transition countries have an advantage of better access 
to the international capital markets which provide cheaper funds than those raised through deposits.

More generally, our results are in line with Demirguc-Kunt and others. (2004) who find that restriction on bank entry and other regulatory obstacles that inhibit the freedom of bankers to conduct their business increase costs of intermediation. We complement this finding by showing that eliminating restrictions on foreign bank ownership boosts performance of acquired banks.

Our findings also contribute to the discussion on fast loan growth in CEECs (e.g., Cottarelli and others, 2005), since we demonstrate that one of the driving forces behind this trend is foreign bank ownership, notwithstanding the mode of entry. Therefore our results complement earlier studies that show that market shares of greenfield banks grow faster than shares of domestic banks (Haas and Lelyveld, 2006). We are able to pick up the effect of foreign ownership on takeover banks due to our matching methodology. As we show in Section 6, foreign investors choose to acquire large institutions in order to gain market power, and naturally such institutions cannot grow as fast as new small banks. However, traditional regression techniques do not take this fact into account, even if the bank size is controlled for. That may result in nonsignificant coefficients for takeover banks.

To further verify the robustness of our results and to get more insight on particular sources of higher profitability of foreign banks after the takeover, we compute the impact of foreign acquisitions on the following variables that capture difference facets of bank performance: net interest margin, capitalization, costs, interest income, interest expenses, size, and loan loss provisions. We first present results in Table 6 for all available banks, and then in Table 7 we show results on the same samples restricted to banks that have continuous information for two and three years after the acquisition. We note that the results are robust notwithstanding the sample.

We find a sign of recapitalization of acquired banks by foreign investors in the year of takeover. In the following two years, the capitalization of foreign banks remains the same as that of domestic banks, but the cumulative results are still significant. This is consistent with the evidence that foreign banks were often only allowed to take over banks which were in the need of recapitalization and restructuring.

Bank recapitalization is the only significant change that the acquired banks undergo in the year of the acquisition. Other changes need more time. The streamlining of costs is only possible two years after the acquisition, when the costs drop by 2.4 percentage points. To see this number in perspective, it is informative to note that average costs of banks that remained in domestic hands are 5.8 percent, indicating over 40 percent drop. This two-year delay can be explained by the presence of agreements that foreign banks had to sign while acquiring a domestic institution, and which prevented them from firing unnecessary personnel or closing 
superfluous branches directly after the acquisition. An alternative explanation for this finding can be based on the results of the theoretical model developed by Detragiache and others. (2008). They show that after the takeover, bank costs can increase because new owners start monitoring the customers. If, in the same time, banks reduce redundant personnel expenses, total costs can stay constant, or start falling only some time after the takeover.

Loan loss provisions of acquired banks start decreasing already one year after the takeover. However, the cumulative effect of lower loan loss provisions appears to be significant only after three years due to a sharp increase in loan loss provisions in the year of the acquisition (which does not turn out to be significant due to high standard errors). This result most likely indicates the reclassification of loans by new owners, who apply tighter classification rules for non-performing loans. If this is the case, the magnitude of our findings that foreign banks have less loan loss provisions is even understated.

Lower loan loss provisions are likely to reflect improved risk management techniques which allow banks to better screen their potential borrowers and thus lower non-performing loans. However, foreign banks are also considered to have comparative advantages at processing hard information, while domestic banks are better at handling soft information. ${ }^{9}$ Therefore, foreign banks might increase their lending to large transparent companies, at the expanse of small entrepreneurs (Dell'Ariccia and Marquez, 2004). Degryse and others. (2008) show that foreign banks that enter via establishment of greenfield operations lend particularly a lot to large private companies and very little to entrepreneurs. The portfolios of foreign banks that entered the market via takeovers of domestic institutions are more similar to domestic banks, but they also tend to lend less to small enterprises. These changes in portfolio composition can also affect costs, since lending that is based on soft information is very labor-intensive. Unfortunately, the BankScope data does not provide portfolio information which could help us to answer this question, and more research is needed to address this issue.

Higher profitability of foreign banks does not stem from higher interest margin, which turns out to be insignificant in our calculations. This is surprising, since one of the recognized advantages of foreign ownership is banks' improved access to the international capital markets either directly or via their parent banks, which should significantly lower their costs

\footnotetext{
${ }^{9}$ Hard and soft information differ with respect to the degree of transferability. Thus, hard information on the other hand refers to credible and publicly verifiable data, such as a firm' balance sheets, credit history, collateral and guarantees. On the other hand, soft information cannot be verified by a third person and is gained a result of the relationship between a bank and a borrower. For example, through repeated interviews with an owner of a young firm, a bank manager might be convinced that the firm's owner is a smart, honest and hard working entrepreneur with a high probability of success. However, this soft information cannot be transferred to other potential lenders (Petersen, 2004).
} 
of funding. ${ }^{10}$ However, if this is passed on to borrowers in terms of lower lending rates in order to increase banks' market share, we would observe no final impact on NIM. To test this, we compute the impact of foreign acquisition separately on interest income and interest expenses of banks. We find a negative influence on both variables, but it is only statistically significant in the case of interest expenses. However, the cumulative results turn out to be significant for both variables. Therefore, we can argue that borrowers directly benefit from lower cost of funding, and this is also the reason why NIM remains stable in the wake of banks' acquisitions.

\section{Additional Robustness Checks}

We have conducted a number of sensitivity analyses, many of which have been already mentioned before. Here we perform some additional robustness checks by constructing new control groups based on new propensity scores which control for additional characteristics that might influence the probability of being acquired and the post-acquisition performance.

We have mentioned before that foreign banks were often allowed to take over domestic banks only in the wake of the crises and/or if target banks experienced financial difficulties. If we do not control for this, the observed improvement in the performance and increase in market share might be coming from a low base and be explained by the selection bias as the worst performing banks were sold to foreign investors. To account for this, we augment our baseline logit model with the lagged value of LLP and compute ATT using this new control group. Alternatively, we augment our baseline model with the crisis dummy, which takes the value of 1 during the years when the crisis hits a country in CEE. The timing of the crisis it taken from the World Bank database "Episodes of Systemic and Borderline Financial Crises" compiled by Caprio and Klingebiel (2003).

The results of the two exercises are presented in Table 8, in panels A and B respectively. It is important to point out that neither the lagged value of LLP, nor the crisis dummy, are significant in the logit regressions. The results for ROA are robust for the first and second year after the takeover, albeit somewhat smaller in magnitude than in our base model. In the third year, the effect remains positive, although it is not significant anymore. The results for market share remain significant, but their magnitude also decreases, especially in the specification with the lagged value of LLP.

The presence of foreign banks in a country has a profound impact on the competition in the market. That, in turn, should improve performance of domestic banks, which can additionally benefit from the spillover effects. This would suggest that it is more difficult to improve

\footnotetext{
${ }^{10}$ Our experience suggests that foreign banks in CEECs have very high share of foreign interbank liabilities, which mostly come from their parent banks. For comparison, domestic banks have virtually zero foreign interbank liabilities.
} 
performance of a domestic bank that is acquired in a country with a high share of foreign banks. To control for this impact, we model the propensity of being acquired by additionally introducing variables that capture the share of foreign banks in the country (Table 9, panel A). Then, we further differentiate between share of greenfield and takeover banks, since banks with different modes of entry can exert different competitive pressure. More specifically, Claeys and Hainz (2007) note that competition on the banking market is stronger when a foreign bank enters via a greenfield investment than via the acquisition.

The results of this exercise are presented in panel B of Table 9. None of the three variables enter significantly the logit regression. The results of treatment effects are similar to the previous robustness check: the impact of foreign acquisition has a positive impact on both ROA and market share. We perform also other similar robustness checks which involve augmenting a propensity model with variables that do not enter significantly in our baseline model, such NIM, costs, the value of bilateral trade, or the change in real effective exchange rate. The results remain robust.

Another concern that might arise regarding our results stems from the fact that, due to data limitations, we choose a control bank from the pool of banks that were domestic in a given year, but do not restrict the country. Therefore, there is a risk that the observed differences between takeover and control banks stem not from the positive impact of foreign acquisitions, but from differences in macroeconomic conditions between countries of takeover and control banks. For example, if macroeconomic conditions were more favorable in countries where takeover banks were located, these banks would be more profitable and would grow faster that control banks located in other countries. To test for this, we regress our measures of differences in performance between takeover and control banks on differences in macroeconomic conditions between host countries of takeover and control banks. We include GDP growth, lending rate, inflation, Herfindahl index (to capture market concentration), and a ratio of FDI and trade to GDP (to control for openness of the economies). None of these variables is significant, indicating that our results stem from the impact of foreign bank ownership and not from differences between countries.

We also check whether our results hold if we use a different matching method. First, we experiment with caliper (or radius) methodology where we impose a restriction on the maximum distance in propensity score between the treated and control banks. This approach limits the number of "bad" matches, which appear of the nearest neighbor is far away, therefore it enhances quality of the remaining matches. The downside might be a smaller number of matches found, which can increase variance of the estimates (Caliendo and Kopeinig, 2005). We limit the search for the nearest neighbor to 25, 50, and 100 closest observations, or we limit the distance in propensity score to 5 percentage points. The final results (available upon request) are not influenced by this exercise. 
Matching based on the nearest neighbor approach (whether there is a restriction on the distance between the treated and control observations or not) trades off high quality of the matches with higher variance of the estimates (due to a smaller number of counterfactuals used). Hence, as a robustness check, we use kernel matching - a non-parametric method that matches treated variables with a weighted average of all variables in the control group that are on common support. Weights depend on the distance (in terms of the propensity score) between the treated variable and each control. We use Gaussian kernel to make sure that higher weight is placed on control observations that are close to the treated banks in terms of the propensity score. Our results turn out to be robust and are available upon request.

\section{Conclusions}

The aim of this paper is to assess the impact of foreign acquisitions on the performance of banks operating in Central and Eastern Europe. We use a combination of propensity score matching and difference-in-difference methodology to account for the possible selection bias that is not controlled by standard regression techniques.

In the first part of our analysis we document that foreign banks preferred to acquire large banks in CEECs, because it was time-consuming and expensive to gain market power through a natural portfolio growth. As to the performance of target banks, we show that acquired banks were on average less profitable but better capitalized than institutions that remained in domestic hands. This reflects the situation that local regulatory authorities decided to sell banks to foreign investors in the wake of the crises when profits were low, but in some cases they recapitalized the banks beforehand to render them more attractive to investors.

The above selection bias makes traditional regression techniques badly suited for the analysis of post-acquisition performance and explains why most studies fail to pick up a significant impact of foreign bank ownership on takeover banks, and find it only in the case of greenfield banks. Negative selection bias in bank performance makes results biased downwards, because new foreign investors have to reform the acquired bank just to make it comparable to local banks in terms of efficiency and profitability. Positive selection bias in bank size, however, also influences findings downwards, since larger banks always grow slower than small young ones.

Controlling for the selection bias, we analyze the post-takeover performance by employing difference-in-difference technique. We find that in the year of the acquisition, foreign investors recapitalize the acquired bank. It takes one more year to achieve an increase of profits, which comes from cutting costs and lowering loan loss provisions. In theory, lower loan loss provisions can reflect better risk management techniques or, alternatively, shifting to more transparent large clients, at the expanse of small entrepreneurs. These changes in the portfolio composition can also lead to higher costs for domestic banks, because lending to opaque clients is based on soft information and is very labor intensive. There is some 
evidence that all these explanations play a role. Unfortunately, the BankScope data does not provide information which can help us to answer these questions, and more research is needed to address this issue.

Another advantage of foreign bank ownership is lower cost of funds, which stems from better reputation and superior access to international capital markets either directly or via the parent banks. We show that this lower cost of funds is passed on to borrowers and, therefore, we do not observe an increase in net interest margin of foreign banks in the post-acquisition period.

Two years after the acquisition, the market share of foreign banks starts to grow. Since this happens after the improvements in banks' performance, we can argue that foreign banks succeeded to increase their market share due to their attractiveness to clients. This would support the "efficiency" hypothesis and would not cause competition problems. Our results are contrary to findings for developed countries, where foreign banks are more likely to sacrifice profits for growth.

Our paper contributes to our understanding of mechanisms through which foreign investors affect the performance of the acquired banks. Our methodology allowed us to pick up the improvements in performance which led to a higher market share of foreign banks. Previous studies did not succeed to document these effects due to the selection bias and due to the fact that it takes some transitional period for new owners to reform an acquired institution. So, to answer the question posed in the title, we can conclude that superior performance of foreign banks is not inherited but earned. 


\section{References}

Arnold, J. and Smarzynska-Javorcik, B., 2007, "Gifted Kids or Pushy Parents? Foreign acquisitions and plant performance in Indonesia," CEPR Discussion Paper 5065, Centre for Economic Policy Research.

Berger, A., 1995, "The Profit-Structure Relationship in Banking - Tests of Market Power and Efficient-Structure Hypotheses," Journal of Money, Credit and Banking 27(2), 404-431.

Berger, A., Demsetz, R. and Strahan, P., 1999, "The Consolidation of Financial Services Industry: Causes, Consequences, and Implications for the Future," Journal of Banking and Finance 23, 153-194.

Berger, A. and Hannan, T., 1998, "The Efficiency Cost of Market Power in the Banking Industry: A Test of the 'Quiet Life' and Related Hypotheses," Review of Economics and Statistics 80, 454-465.

Berger, A., Miller, N., Petersen, M., Rajan, R. and Stein, J., 2005, "Does Function Follow Organizational Form? Evidence from the Lending Practices of Large and Small Banks," Journal of Financial Economics 76, 237-269.

Blandon, J., 2001, “The Timing of Foreign Direct Investment under Uncertainty: Evidence from the Spanish Banking Sector," Journal of Economic Behavior and Organization 45(2), 213-224.

Blundell, R. and M., C. D. (2000), "Evaluation Methods for Nonexperimental Data", Fiscal Studies 21(4), 427-468.

Bonin, J., Hasan, I. and Wachtel, P., 2005, "Bank Performance, Efficiency and Ownership in Transition Countries," Journal of Banking and Finance 29, 31-53.

Buch, C., 2000a, "Capital Market Integration in Euroland - the Role of Banks," German Economic Review 1(4), 443-464.

Buch, C., 2000b, "Why do Banks go Abroad?: Evidence from German Data," Financial Markets, Institutions and Intruments 9(1), 33-67.

Buch, C. and DeLong, G., 2004, "Cross-Border Bank Mergers: What Lures the Rare Animal?', Journal of Banking and Finance 28(9), 2077-2102.

Buch, C. and Lipponer, A., 2000, "Clustering or Competition: The Foreign Investment Behavior of German Banks," International Journal of Central Banking 5, 135168.

Caliendo, M. and Kopeinig, S., 2005, "Some Practical Guidance for the Implementation of Propensity Score Matching", mimeo. 
Caprio, G. and Klingebiel, D., 2003, "Episodes of Systemic and Borderline Financial Crises", World Bank database.

Claessens, S., Demirguc, A. and Huizinga, H., 2001, "How do Foreign Entry Affect Domestic Banking Markets?” Journal of Banking and Finance 25, 891-911.

Claeys, S. and Hainz, C., 2007, “Acquisition versus Greenfield: the Impact of the Mode of Foreign Bank Entry on Information and Bank Lending Rates", mimeo.

Cottarelli, C., Dell'Ariccia, G. and Vladkova-Hollar, I., 2005, "Early Birds, late Risers, and Sleeping Beauties: Bank Credit Growth to the Private Sector in Central and Eastern Europe and in the Balkans," Journal of Banking and Finance 29(1), 83104.

De Haas, R. and Van Lelyveld, I., 2006, "Foreign Banks and Credit Stability in Central and Eastern Europe: A Panel Data Analysis?" Journal of Banking and Finance 30(7), 1927-1952.

De Loecker, J., 2007, "Do Exports Generate Higher Productivity? Evidence from Slovenia," Journal of International Economics 73(1), 69-98.

Degryse, H., Havrylchhyk, O., Jurzyk, E. and Kozak, S., 2008, “The Effect of Foreign Bank Entry on the Cost of Credit in Transition Economies. Which Borrowers Benefit Most?” CEPII Working Paper No. 15.

Dell'Ariccia, G. and Marquez, R., 2004, "Information and Bank Credit Allocation”, Journal of Financial Economics 72, 185-214.

Demirguc-Kunt, A., Laeven, L. and Levine, R., 2004, "Regulations, Market structure, Institutions, and the Cost of Financial Intermediation," Journal of Money, Credit and Banking 36(3), 593-622.

Demsetz, H., 1973, “Industry Structure, Market Rivalry, and Public Policy,” Journal of Law and Economics 16(1), 1-9.

Detragiache, E., Tressel, T. and Gupta, P., 2008, "Foreign Banks in Poor Countries: Theory and Evidence," Journal of Finance 63(5), 2123 - 2160.

DeYoung, R. and Nolle, D., 1996, "Foreign-Owned Banks in the United States: Earning Market Share of buying it?" Journal of Money, Credit and Banking 28(4), 622636.

Dooley, M. P. and Shin, I., 2004, "Foreign Bank Entry into Emerging Economies: An Empirical Assessment of the Determinants and Risks Predicated on German FDI data," Deutsche Bundesbank Discussion Paper 01, Deutsche Bundesbank.

Drucker, S. and Puri, M., 2005, "On the Benefits of Concurrent Lending and Underwriting," Journal of Finance 60(6), 2763-2800. 
Giannetti, M. and Ongena, S., 2008, "Financial Integration and Firm Performance: Evidence from Foreign Bank Entry in Emerging Markets," Review of Finance, forthcoming.

Grubel, H., 1977, “A Theory of Multinational Banking,” Technical report, Banca Nazionale del Lavoro Quarterly Review.

Havrylchyk, O. and Jurzyk, E., 2005, "Profitability of Foreign banks in Central and Eastern Europe: Does the Mode of Entry Matter?" CEPII Working Paper No. 21.

Heckman, J., Ichimura, H. and Todd, P., 1997, "Matching as an Econometric Evaluation Estimator: Evidence from Evaluation a Job Training Program," Review of Economic Studies 64, 605-654.

Heckman, J., Ichimura, H. and Todd, P., 1998, "Matching as an Econometric Evaluation Estimator," Review of Economic Studies 65, 261-294.

Ioannidou, V. and Ongena, S., 2008, "Time for a Change": Loan Conditions and Bank Behavior when Firms Switch," mimeo

La Porta, R., Lopez-De-Silanes, F. and Shleifer, A., 2002, "Government Ownership of Banks," Journal of Finance 57(1), $265-301$.

Lane, P. and Milesi-Ferretti, G. M., 2006, "The External Wealth of Nations Mark II: Revised and Extended Estimates of Foreign Assets and Liabilities," IMF Working Paper 06/69, International Monetary Fund.

Lanine, G. and Vander Vennet, R., 2007, "Microeconomic Determinants of Acquisitions of Eastern European Banks by Western European banks," Economics of Transition 15(2), 285-308.

Magri, S., Mori, A. and Rossi, P., 2005, "The Entry and the Activity Level of Foreign Banks in Italy: An Analysis of the Determinants," Journal of Banking and Finance 29, 1295-1310.

Martinez Peria, M. S. and Mody, A., 2004, "How Foreign Participation and Market Concentration Impact Bank Spreads: Evidence from Latin America," Journal of Money, Credit and Banking 36(3), 511-537.

Peek, J., Rosengren, E. and Kasirye, F., 1999, "The Poor Performance of Foreign Bank Subsidiaries: Were the Problems Acquired or Created?" Journal of Banking and Finance 23(2/4), 579-604.

Rosenbaum, P. and Rubin, D., 1983a, "Assessing Sensitivity to an Unobserved Binary Covariate in an Observational Study with Binary Outcome," Journal of the Royal Statistical Society 45, 212-218.

Rosenbaum, P. and Rubin, D., 1983b, "The Central Role of the Propensity Score in Observational Studies for Causal Effects," Biometrika 70(1), 41-55. 
Rosenbaum, P. and Rubin, D., 1984, "Reducing Bias in Observational Studies Using Subclassification on the Propensity score," Journal of the American Statistical Association 79, 516-524.

Shepherd,W., 1982, "Economies of Scale and Monopoly Profits," in J. Craven, ed., 'Industrial Organization, Antitrust, and Public Policy', Kluwer Nihoff, Boston.

Smith, J. and Todd, P., 2005, “Does Matching Overcome LaLonde's Critique of Nonexperimental Estimators?,” Journal of Econometrics 2125, 305-353.

Williams, B., 1998a, "Factors Affecting the Performance of Foreign-Owned Banks in Australia: A Cross-Sectional Study," Journal of Banking and Finance 22, $197-$ 219.

Williams, B., 1998b, "A Pooled Study of the Profits and Size of Foreign Banks in Australia," Journal of Multinational Financial Management 8, 211-231.

Williams, B., 2003, "Domestic and International Determinants of Bank Profits: Foreign Banks in Australia," Journal of Banking and Finance 27, 1185-1210.

Yamori, N., 1998, "A Note on the Location Choice of Multinational Banks: The Case of Japanese Financial Institutions," Journal of Banking and Finance 22, 109-120. 
Table 1. Description of Variables

\begin{tabular}{|c|c|c|}
\hline Symbol & Description & Data source \\
\hline ROA & $\begin{array}{l}\text { Return on assets, calculated as ratio of profits after taxes to total } \\
\text { assets }\end{array}$ & BankScope \\
\hline NIM & $\begin{array}{l}\text { Net interest margin, calculated as ratio of net interest income to } \\
\text { total assets }\end{array}$ & BankScope \\
\hline CAP & $\begin{array}{l}\text { Bank capitalization, calculated as a ratio of bank equity capital to } \\
\text { total assets }\end{array}$ & BankScope \\
\hline Costs & Ratio of personnel and other operating expenses to total assets & BankScope \\
\hline Crisis & $\begin{array}{l}\text { Dummy taking the value of } 1 \text { for countries experiencing a } \\
\text { banking crisis }\end{array}$ & $\begin{array}{l}\text { Caprio and Klingebiel } \\
(2003)\end{array}$ \\
\hline Interest income & Ratio of interest income to total assets & BankScope \\
\hline Interest expense & Ratio of interest expense to total assets & BankScope \\
\hline LLP & $\begin{array}{l}\text { Loan loss provisions, calculated as ratio of loan loss provisions to } \\
\text { interest income (in percent). }\end{array}$ & BankScope \\
\hline Size & Bank size, calculated as a logarithm of bank assets & BankScope \\
\hline Market Share & $\begin{array}{l}\text { Share of loans of a bank in the total loans of banking sector in } \\
\text { host country }\end{array}$ & BankScope \\
\hline Lending rate & Average bank lending rate adjusted for inflation & IFS \\
\hline GDP & Real rate of growth of GDP & $\begin{array}{l}\text { World Development } \\
\text { Indicators }\end{array}$ \\
\hline GDP_PC & Logarithm of real GDP per capita & $\begin{array}{l}\text { World Development } \\
\text { Indicators }\end{array}$ \\
\hline FDI & Ratio of FDI to GDP & Lane and Milesi Ferretti \\
\hline Trade & Ratio of sum of exports and imports to GDP & $\begin{array}{l}\text { World Development } \\
\text { Indicators }\end{array}$ \\
\hline Public & $\begin{array}{l}\text { Dummy taking a value of } 1 \text { for banks where over } 50 \% \text { of capital } \\
\text { is owned by the state }\end{array}$ & Own research \\
\hline EBRD & EBRD index of competition reforms & EBRD Transition Reports \\
\hline
\end{tabular}


Table 2. Descriptive Statistics

\begin{tabular}{|c|c|c|c|c|c|c|}
\hline & & Mean & Std. Dev. & $\mathrm{A}$ & B & $\mathrm{C}$ \\
\hline \multirow[t]{4}{*}{ ROA } & Domestic & 0.416 & 7.188 & & & \\
\hline & Takeover & 0.544 & 4.595 & & & \\
\hline & Before & 0.378 & 5.937 & & & \\
\hline & After & 0.691 & 2.932 & & & \\
\hline \multirow[t]{4}{*}{ NIM } & Domestic & 4.602 & 4.823 & & & \\
\hline & Takeover & 4.108 & 2.740 & $* * *$ & & \\
\hline & Before & 4.491 & 4.823 & & & \\
\hline & After & 3.768 & 2.148 & & $* * *$ & $* * *$ \\
\hline \multirow[t]{4}{*}{ CAP } & Domestic & 15.208 & 13.535 & & & \\
\hline & Takeover & 12.735 & 12.081 & $* * *$ & & \\
\hline & Before & 12.186 & 13.756 & & $* * *$ & \\
\hline & After & 13.221 & 10.363 & & $* * *$ & \\
\hline \multirow[t]{4}{*}{ Costs } & Domestic & 5.791 & 14.922 & & & \\
\hline & Takeover & 4.312 & 7.653 & $* * *$ & & \\
\hline & Before & 4.470 & 8.658 & & * & \\
\hline & After & 4.169 & 6.620 & & $* *$ & \\
\hline \multirow[t]{4}{*}{ Interest income } & Domestic & 10.464 & 7.293 & & & \\
\hline & Takeover & 9.952 & 6.184 & & & \\
\hline & Before & 12.505 & 7.612 & & $* * *$ & \\
\hline & After & 8.074 & 3.936 & & $* * *$ & $* * *$ \\
\hline \multirow[t]{4}{*}{ Interest expense } & Domestic & 5.835 & 5.883 & & & \\
\hline & Takeover & 5.725 & 5.661 & & & \\
\hline & Before & 8.018 & 7.399 & & $* * *$ & \\
\hline & After & 4.039 & 2.950 & & $* * *$ & $* * *$ \\
\hline \multirow[t]{4}{*}{ Market share } & Domestic & 4.349 & 9.018 & & & \\
\hline & Takeover & 9.037 & 11.943 & $* * *$ & & \\
\hline & Before & 10.511 & 13.439 & & $* * *$ & \\
\hline & After & 7.732 & 10.278 & & $* * *$ & $* * *$ \\
\hline \multirow[t]{4}{*}{ Size } & Domestic & 12.116 & 1.651 & & & \\
\hline & Takeover & 13.373 & 1.754 & $* * *$ & & \\
\hline & Before & 13.130 & 1.748 & & $* * *$ & \\
\hline & After & 13.583 & 1.732 & & $* * *$ & $* * *$ \\
\hline \multirow[t]{4}{*}{ LLP } & Domestic & 14.893 & 56.235 & & & \\
\hline & Takeover & 13.175 & 87.636 & & & \\
\hline & Before & 15.015 & 28.137 & & & \\
\hline & After & 11.525 & 117.769 & & & \\
\hline
\end{tabular}

${ }^{* * *},{ }^{* *},{ }^{*}$ correspond to 1 percent, 5 percent and 10 percent significance levels that the following differences in means are different from zero: in column A between takeover and domestic banks, in column B - between takeover banks before takeover, takeover banks after takeover, and domestic banks respectively, in column $\mathrm{C}$ - between takeover banks before and after takeover. 
Table 3. Logit Regression

Dependent Variable: Foreign acquisition

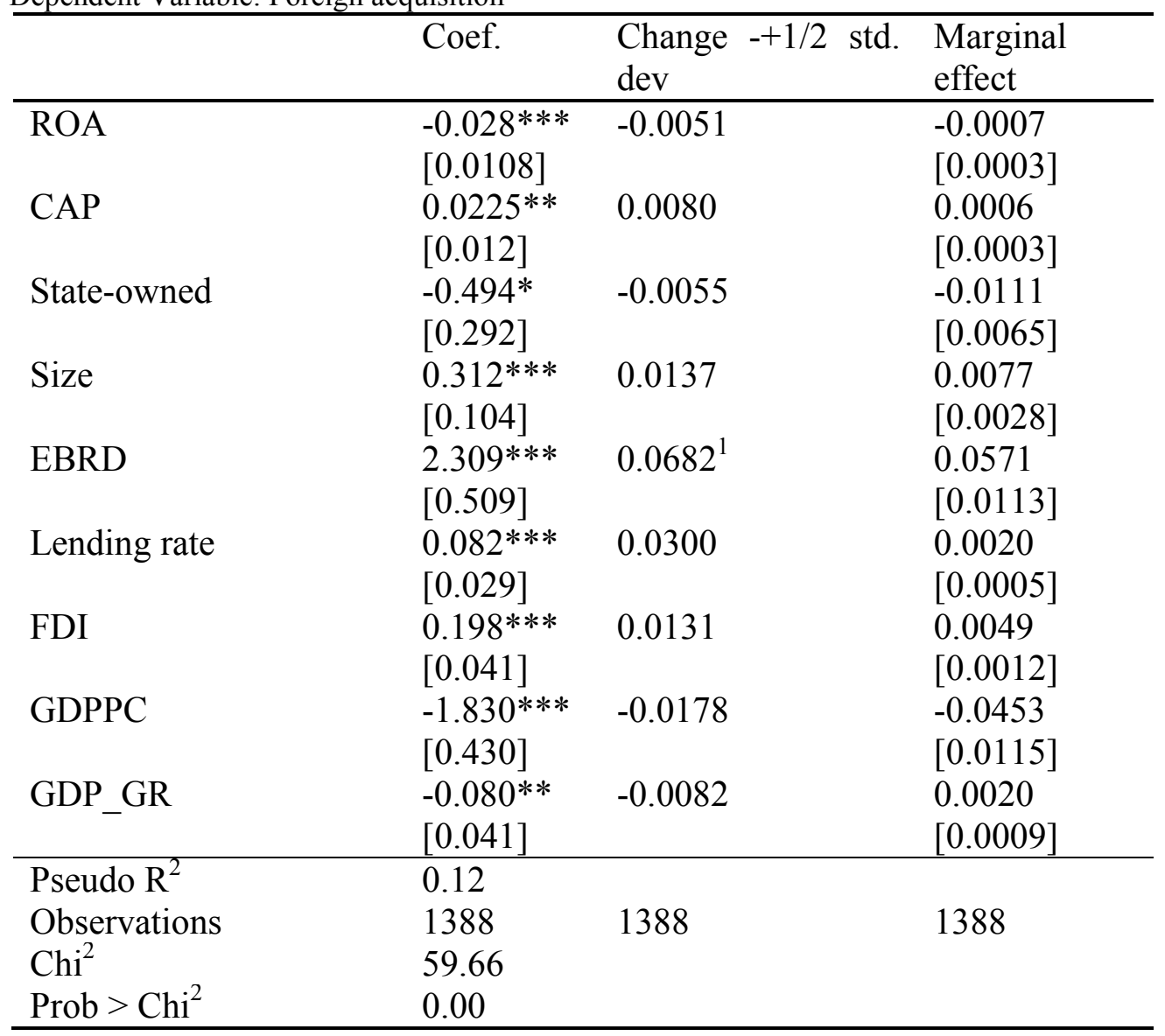

The table lists coefficients and standard errors (in parentheses) in column 1, the impact of the change of one standard deviation of the right-hand-side variable on the dependent variable (column 2), and marginal effects (column 3). All dependent variables are lagged by one year. Regressions include seasonal dummies. Definitions of variables are provided in Table $2 . * * *, * *$, and $*$ correspond to 1 percent, 5 percent and 10 percent significance levels. Since EBRD index is not a continuous variable, we present the effects of increase in the index by 1 unit. 
Table 4. Results of the Matching Procedure for ROA and Market Share

\begin{tabular}{llll}
\hline & ROA & Market share & No. of observation: \\
\hline Panel A: Annual effects & & & \\
\hline Acquisition year & 0.094 & 0.304 & 73 \\
& {$[0.834]$} & {$[0.577]$} & \\
One year later & $2.556^{* * *}$ & 0.819 & 69 \\
& {$[1.011]$} & {$[0.688]$} & \\
Two years later & $2.084^{* * *}$ & $1.843^{* *}$ & 61 \\
& {$[1.001]$} & {$[0.884]$} & \\
Three years later & $1.714^{*}$ & $2.288^{* *}$ & 54 \\
& {$[0.968]$} & {$[0.978]$} & \\
\hline \multirow{3}{*}{ Panel B: Cumulative results } & & & \\
\hline One year later & $2.775^{*}$ & 1.272 & 69 \\
Two years later & {$[1.579]$} & {$[1.286]$} & \\
& $4.968^{* *}$ & $3.404^{*}$ & 61 \\
Three years later & {$[2.444]$} & {$[2.009]$} & \\
& $7.795^{* *}$ & $5.686^{*}$ & 54 \\
\hline
\end{tabular}

The table lists coefficients and bootstrapped standard errors (in parentheses) of the Difference in Difference methodology for estimating the impact of foreign acquisitions on ROA and Market share of takeover banks. Annual effects are presented in Panel A, and cumulative effects in Panel B. Definitions of variables are provided in Table $2 . * * *, * *$, and * correspond to 1 percent, 5 percent and 10 percent significance levels. 
Table 5. Results of the Matching Procedure for ROA and Market Share-Same Sample Size

\begin{tabular}{lllll}
\hline & ROA & Market share & ROA & Market share \\
\hline Acquisition year & 0.059 & 0.5885 & 0.538 & 0.552 \\
& {$[0.907]$} & {$[0.649]$} & {$[0.922]$} & {$[0.750]$} \\
One year later & $2.944^{* * *}$ & 0.976 & $3.189^{* * *}$ & 1.006 \\
& {$[1.135]$} & {$[0.739]$} & {$[1.259]$} & {$[0.865]$} \\
Two years later & $2.084^{* * *}$ & $1.843^{* *}$ & $2.354^{* *}$ & $1.840^{*}$ \\
& {$[1.001]$} & {$[0.884]$} & {$[1.141]$} & {$[1.022]$} \\
Three years later & & & $1.714^{*}$ & $2.288^{* *}$ \\
& & & {$[0.968]$} & {$[0.978]$} \\
\hline No. of observations & 61 & 61 & 54 & 54 \\
\hline
\end{tabular}

The table lists coefficients and bootstrapped standard errors (in parentheses) of the Difference in Difference methodology for estimating the impact of foreign acquisitions on ROA and Market share of takeover banks. First two columns present the results for the same sample up to two years after the takeover, columns 3 and 4 for three years after the takeover. Definitions of variables are provided in Table 2. ***, **, and * correspond to 1 percent, 5 percent and 10 percent significance levels. 
Table 6. Results of the Matching Procedure-Decomposition of ROA and Size

\begin{tabular}{|c|c|c|c|c|c|c|c|c|}
\hline & NIM & CAP & Costs & $\begin{array}{l}\text { Interest } \\
\text { income }\end{array}$ & $\begin{array}{l}\text { Interest } \\
\text { expense }\end{array}$ & Size & LLP & $\begin{array}{l}\text { No. of } \\
\text { Obs. }\end{array}$ \\
\hline \multicolumn{9}{|c|}{ Panel A: Annual effects } \\
\hline Acquisition year & $\begin{array}{l}-0.480 \\
{[0.371]}\end{array}$ & $\begin{array}{l}2.755^{*} \\
{[1.557]}\end{array}$ & $\begin{array}{l}-3.195 \\
{[3.200]}\end{array}$ & $\begin{array}{l}-0.953 \\
{[0.705]}\end{array}$ & $\begin{array}{l}-0.473 \\
{[0.562]}\end{array}$ & $\begin{array}{l}0.052 \\
{[0.816]}\end{array}$ & $\begin{array}{l}22.790 \\
{[33.468]}\end{array}$ & 73 \\
\hline One year later & $\begin{array}{l}0.226 \\
{[0.367]}\end{array}$ & $\begin{array}{l}2.878 \\
{[1.816]}\end{array}$ & $\begin{array}{l}-0.558 \\
{[2.109]}\end{array}$ & $\begin{array}{l}-0.697 \\
{[0.705]}\end{array}$ & $\begin{array}{l}-0.923^{*} \\
{[0.561]}\end{array}$ & $\begin{array}{l}0.161 * * \\
{[0.076]}\end{array}$ & $\begin{array}{l}-16.014 * * * \\
{[4.763]}\end{array}$ & 69 \\
\hline Two years later & $\begin{array}{l}-0.016 \\
{[0.422]}\end{array}$ & $\begin{array}{l}1.711 \\
{[2.009]}\end{array}$ & $\begin{array}{l}-2.395 * *: \\
{[0.948]}\end{array}$ & $\begin{array}{l}-1.212 \\
{[0.910]}\end{array}$ & $\begin{array}{l}-1.196^{*} \\
{[0.719]}\end{array}$ & $\begin{array}{l}0.322 * * * \\
{[0.097]}\end{array}$ & $\begin{array}{l}-13.806^{* * *} \\
{[4.972]}\end{array}$ & 61 \\
\hline Three years later & $\begin{array}{l}0.368 \\
{[0.502]}\end{array}$ & $\begin{array}{l}3.540^{*} \\
{[1.992]}\end{array}$ & $\begin{array}{l}-1.578^{* *}: \\
{[0.539]}\end{array}$ & $\begin{array}{l}-0.899 \\
{[1.072]}\end{array}$ & $\begin{array}{l}-1.268^{*} \\
{[0.775]}\end{array}$ & $\begin{array}{l}0.348^{* * *} \\
{[0.114]}\end{array}$ & $\begin{array}{l}-13.782 * * \\
{[6.828]}\end{array}$ & 54 \\
\hline \multicolumn{9}{|c|}{ Panel B: Cumulative effects } \\
\hline Acquisition year & $\begin{array}{l}-0.480 \\
{[0.371]}\end{array}$ & $\begin{array}{l}2.755^{*} \\
{[1.557]}\end{array}$ & $\begin{array}{l}-3.195 \\
{[3.200]}\end{array}$ & $\begin{array}{l}-0.953 \\
{[0.705]}\end{array}$ & $\begin{array}{l}-0.473 \\
{[0.562]}\end{array}$ & $\begin{array}{l}0.052 \\
{[0.816]}\end{array}$ & $\begin{array}{l}22.790 \\
{[33.468]}\end{array}$ & 73 \\
\hline One year later & $\begin{array}{l}-0.066 \\
{[0.628]}\end{array}$ & $\begin{array}{l}6.154^{*} \\
{[3.232]}\end{array}$ & $\begin{array}{l}-4.091^{*} \\
{[2.222]}\end{array}$ & $\begin{array}{l}-1.954 \\
{[1.250]}\end{array}$ & $\begin{array}{l}-1.888^{*} \\
{[0.985]}\end{array}$ & $\begin{array}{l}0.236^{*} \\
{[0.134]}\end{array}$ & $\begin{array}{l}12.737 \\
{[33.604]}\end{array}$ & 69 \\
\hline Two years later & $\begin{array}{l}-0.461 \\
{[1.045]}\end{array}$ & $\begin{array}{l}9.177^{*} \\
{[5.163]}\end{array}$ & $\begin{array}{l}-5.461 * * \\
{[2.341]}\end{array}$ & $\begin{array}{l}-3.818^{*} \\
{[2.221]}\end{array}$ & $\begin{array}{l}-3.357^{*} \\
{[1.786]}\end{array}$ & $\begin{array}{l}0.572 * * \\
{[0.236]}\end{array}$ & $\begin{array}{l}4.729 \\
{[36.479]}\end{array}$ & 61 \\
\hline Three years later & $\begin{array}{l}0.155 \\
{[1.656]}\end{array}$ & $\begin{array}{l}16.290^{* *} \\
{[6.640]}\end{array}$ & $\begin{array}{l}-7.660^{* *:} \\
{[2.714]}\end{array}$ & $\begin{array}{l}-5.530^{*} \\
{[3.336]}\end{array}$ & $\begin{array}{l}-5.684 * * \\
{[2.592]}\end{array}$ & $\begin{array}{l}0.944 * * * \\
{[0.357]}\end{array}$ & $\begin{array}{l}-42.166^{* *} \\
{[16.600]}\end{array}$ & 54 \\
\hline
\end{tabular}

The table lists coefficients and bootstrapped standard errors (in parentheses) of the Difference in Difference methodology for estimating the impact of foreign acquisitions on NIM, CAP, Costs, Interest Income, Interest Expense, Size, and LLP. Annual effects are presented in Panel A, and cumulative effects in Panel B. Definitions of variables are provided in Table 2. ***, **, and * correspond to 1 percent, 5 percent and 10 percent significance levels. 
Table 7. Results of the Matching Procedure-Sample Restricted to Two and Three Years After Takeover

\begin{tabular}{|c|c|c|c|c|c|c|c|}
\hline & NIM & CAP & Costs & $\begin{array}{l}\text { Interest } \\
\text { income }\end{array}$ & $\begin{array}{l}\text { Interest } \\
\text { expense }\end{array}$ & Size & LLP \\
\hline \multicolumn{8}{|c|}{ Sample restricted to 2 years } \\
\hline \multirow[t]{2}{*}{ Acquisition year } & -0.338 & $3.422 * *$ & -0.346 & $-1.382 * *$ & $-1.045 * *$ & 0.077 & 35.812 \\
\hline & {$[0.318]$} & {$[1.716]$} & {$[0.633]$} & {$[0.683]$} & {$[0.543]$} & {$[0.066]$} & {$[40.685]$} \\
\hline \multirow[t]{2}{*}{ One year later } & -0.108 & $4.045 * *$ & $-2.721 *$ & $-1.224 *$ & $-1.117^{*}$ & $0.173 * *$ & $-17.278 * * *$ \\
\hline & {$[0.369]$} & [1.942] & {$[1.505]$} & {$[0.749]$} & {$[0.617]$} & {$[0.084]$} & {$[5.187]$} \\
\hline \multirow[t]{2}{*}{ Two years later } & -0.016 & 1.711 & $-2.395 * * *$ & -1.212 & -1.196 & $0.322 * * *$ & $-13.806^{* * *}$ \\
\hline & {$[0.422]$} & [2.009] & {$[0.948]$} & {$[0.910]$} & {$[0.719]^{*}$} & {$[0.097]$} & [4.972] \\
\hline No. of obs. & 61 & 61 & 61 & 61 & 61 & 61 & 61 \\
\hline \multicolumn{8}{|c|}{ Sample restricted to 3 years } \\
\hline \multirow[t]{2}{*}{ Acquisition year } & -0.332 & $4.174 * * *$ & -0.641 & $-1.709 * *$ & $-1.377 * *$ & 0.089 & -4.305 \\
\hline & {$[0.346]$} & {$[1.588]$} & {$[0.526]$} & {$[0.739]$} & {$[0.559]$} & {$[0.061]$} & {$[4.402]$} \\
\hline \multirow[t]{2}{*}{ One year later } & 0.002 & $5.326 * * *$ & $-3.018 * *$ & $-1.506^{*}$ & $-1.507 * *$ & $0.186 * *$ & $-13.010 * * *$ \\
\hline & {$[0.423]$} & {$[1.867]$} & {$[1.561]$} & {$[0.843]$} & {$[0.651]$} & {$[0.089]$} & [4.697] \\
\hline \multirow[t]{2}{*}{ Two years later } & 0.117 & 3.250 & $-2.424 * *$ & -1.415 & $-1.532 * *$ & $0.321 * * *$ & $-11.069 * *$ \\
\hline & {$[0.238]$} & [2.118] & {$[1.058]$} & [1.019] & {$[0.768]$} & {$[0.111]$} & {$[4.632]$} \\
\hline \multirow[t]{2}{*}{ Three years later } & 0.368 & $3.540^{*}$ & $-1.578 * * *$ & -0.899 & $-1.268 *$ & $0.348 * * *$ & $-13.782 * *$ \\
\hline & {$[0.502]$} & [1.992] & {$[0.539]$} & [1.072] & {$[0.775]$} & {$[0.114]$} & {$[6.828]$} \\
\hline No. of obs. & 54 & 54 & 54 & 54 & 54 & 54 & 54 \\
\hline
\end{tabular}

The table lists coefficients and bootstrapped standard errors (in parentheses) of the Difference in Difference methodology for estimating the impact of foreign acquisitions on NIM, CAP, Costs, Interest Income, Interest Expense, Size, and LLP with a sample restricted to two years after the takeover (panel A) and three years after the takeover (panel B). Definitions of variables are provided in Table 2. ***, **, and * correspond to 1 percent, 5 percent and 10 percent significance levels. 
Table 8. Results of the Matching Procedure for ROA and Market Share.

Sample matched on lagged LLP and occurrence of crisis

\begin{tabular}{|c|c|c|c|}
\hline & $\mathrm{ROA}$ & Market share & No. of observations \\
\hline \multicolumn{4}{|c|}{ Sample matched on lagged LLP } \\
\hline \multirow[t]{2}{*}{ Acquisition year } & 0.053 & 0.068 & 73 \\
\hline & {$[0.817]$} & {$[0.428]$} & \\
\hline \multirow[t]{2}{*}{ One year later } & $2.010 * *$ & 0.400 & 69 \\
\hline & {$[1.005]$} & {$[0.451]$} & \\
\hline \multirow[t]{2}{*}{ Two years later } & $2.026^{*}$ & $0.988 * *$ & 61 \\
\hline & {$[1.079]$} & {$[0.476]$} & \\
\hline \multirow[t]{2}{*}{ Three years later } & 1.474 & $1.156^{*}$ & 54 \\
\hline & {$[0.984]$} & {$[0.480]$} & \\
\hline \multicolumn{4}{|c|}{ Sample matched on occurrence of crisis } \\
\hline \multirow[t]{2}{*}{ Acquisition year } & -0.316 & 0.284 & 73 \\
\hline & {$[0.750]$} & {$[0.433]$} & \\
\hline \multirow[t]{2}{*}{ One year later } & $2.491 * *$ & $1.313^{*}$ & 65 \\
\hline & {$[1.044]$} & {$[0.702]$} & \\
\hline \multirow[t]{2}{*}{ Two years later } & $2.020 *$ & $1.978 * *$ & 56 \\
\hline & [1.172] & [0.930] & \\
\hline \multirow[t]{2}{*}{ Three years later } & 0.742 & $1.519 * *$ & 49 \\
\hline & [1.081] & {$[0.656]$} & \\
\hline
\end{tabular}

The table lists coefficients and bootstrapped standard errors (in parentheses) of the Difference in Difference methodology for estimating the impact of foreign acquisitions on ROA and Market Share. Panel A presents the results of DID when the initial matching was performed with a lagged LLP variable added in the logit model, Panel B - with the lagged crisis dummy added to the logit model. Neither the LLP not the crisis dummy were significant in the logit regressions.

Definitions of variables are provided in Table $2 . * * *, * *$, and $*$ correspond to percent, 5 percent and 10 percent significance levels. 
Table 9. Results of the matching procedure for ROA and Market Share.

Sample matched on Share Foreign, and Share of Takeover and Greenfield banks.

Effects of foreign acquisition (ATT)

\begin{tabular}{|c|c|c|c|}
\hline & ROA & Market share & No. of observations \\
\hline \multicolumn{4}{|c|}{ Sample matched on Share Foreign } \\
\hline Acquisition year & $\begin{array}{l}-0.457 \\
{[0.915]}\end{array}$ & $\begin{array}{l}0.480 \\
{[0.960]}\end{array}$ & 73 \\
\hline One year later & $\begin{array}{l}1.971^{*} \\
{[1.171]}\end{array}$ & $\begin{array}{l}0.091 \\
0.434\end{array}$ & 69 \\
\hline Two years later & $\begin{array}{l}2.174^{*} \\
{[1.241]}\end{array}$ & $\begin{array}{l}0.964 * \\
{[0.529]}\end{array}$ & 61 \\
\hline Three years later & $\begin{array}{l}1.114 \\
{[0.985]}\end{array}$ & $\begin{array}{l}1.546 * * \\
{[0.655]}\end{array}$ & 54 \\
\hline \multicolumn{4}{|c|}{ Sample matched on Share Greenfield and Takeover } \\
\hline Acquisition year & $\begin{array}{l}-0.216 \\
{[0.914]}\end{array}$ & $\begin{array}{l}0.546 \\
{[0.961]}\end{array}$ & 73 \\
\hline One year later & $\begin{array}{l}2.019^{*} \\
{[1.169]}\end{array}$ & $\begin{array}{l}0.206 \\
{[0.432]}\end{array}$ & 69 \\
\hline Two years later & $\begin{array}{l}1.825^{*} \\
{[1.045]}\end{array}$ & $\begin{array}{l}1.157 * * \\
{[0.520]}\end{array}$ & 61 \\
\hline Three years later & $\begin{array}{l}1.362 \\
{[1.095]}\end{array}$ & $\begin{array}{l}1.603 * * * \\
{[0.615]}\end{array}$ & 54 \\
\hline
\end{tabular}

The table lists coefficients and bootstrapped standard errors (in parentheses) of the Difference in Difference methodology for estimating the impact of foreign acquisitions on ROA and Market Share. Panel A presents the results of DID when the initial matching was performed with a lagged Share Foreign variable added in the logit model, Panel B - with the lagged Share Greenfield and Share Takeover added to the logit model. Neither variable was significant in the logit regressions. Definitions of variables are provided in Table 2. ***, **, and * correspond to 1 percent, 5 percent and 10 percent significance levels. 
Figure 1. ROA Trajectories for Takeover, Greenfield, and Domestic Banks

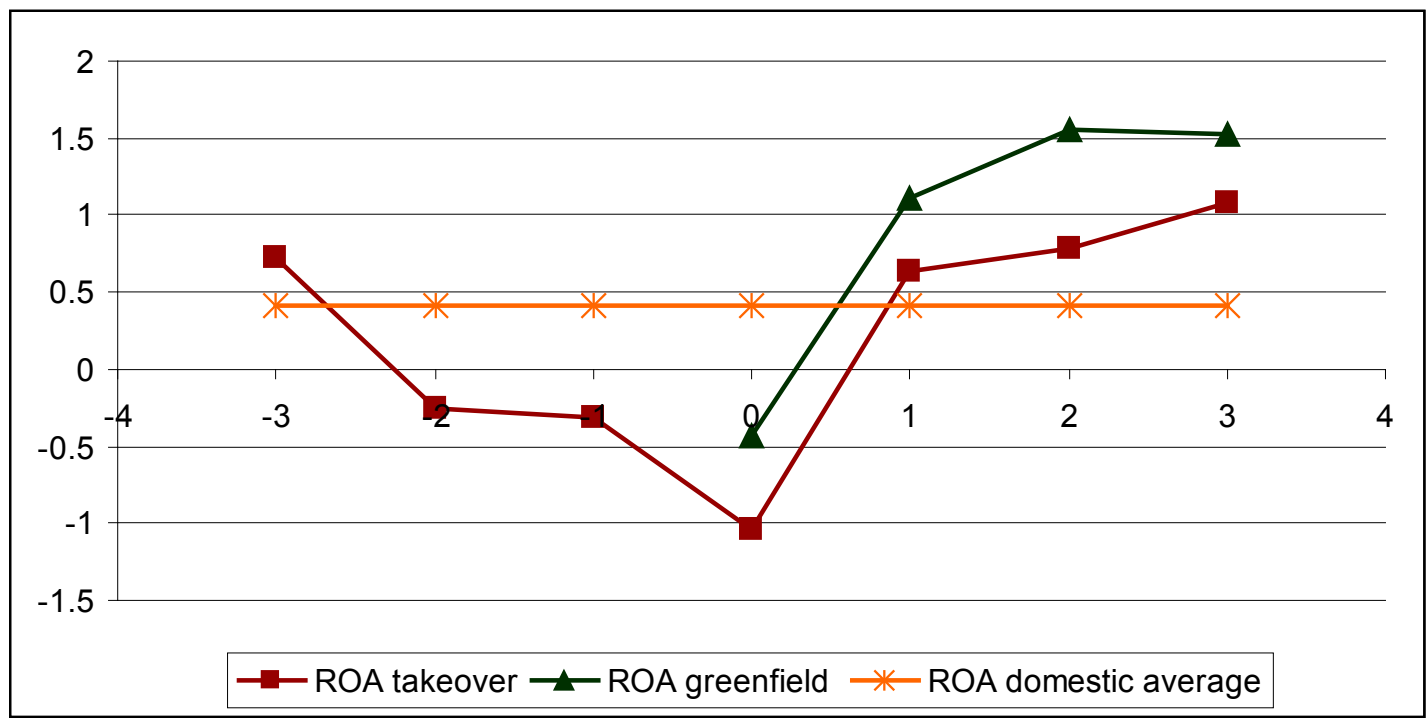

0 indicates year of takeover for takeover banks or year of establishment for greenfield banks

Figure 2. Market Share Trajectories for Takeover, Greenfield, and Domestic Banks

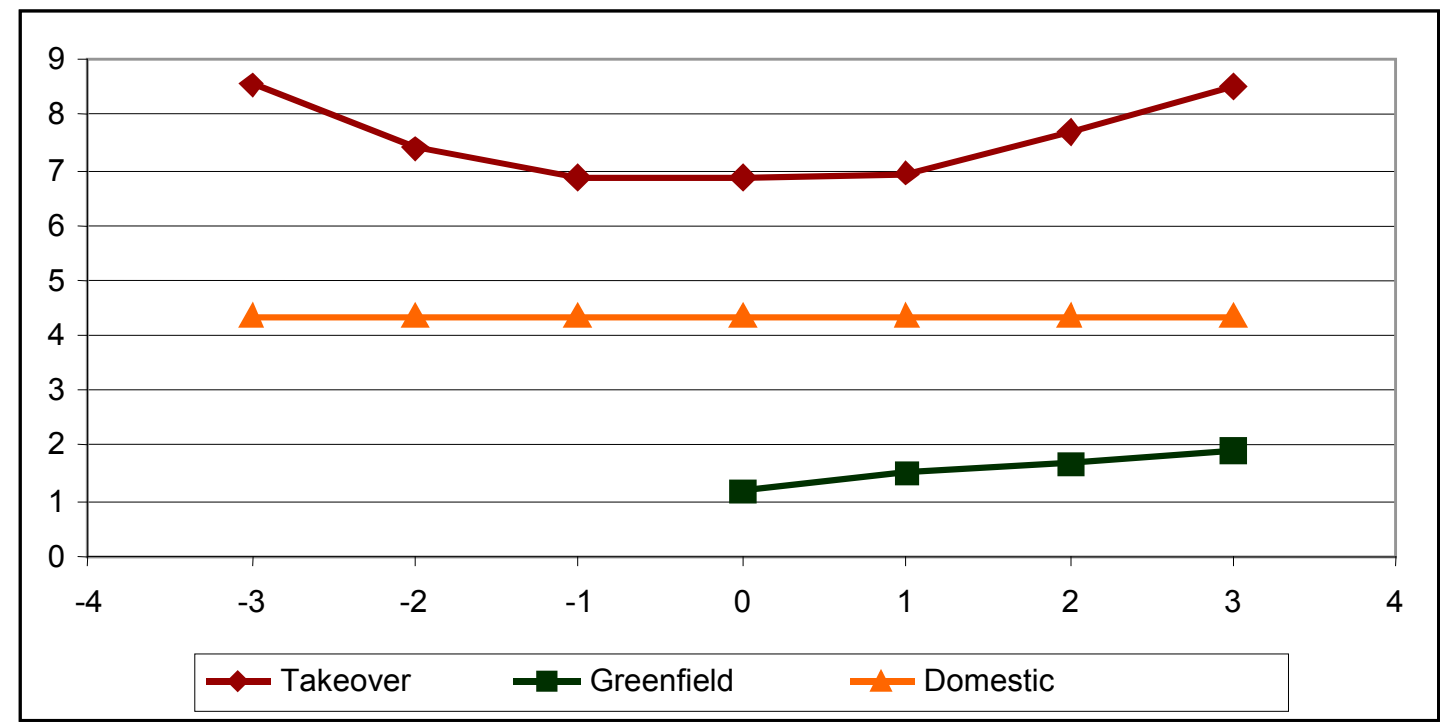

0 indicates year of takeover for takeover banks or year of establishment for greenfield banks 
Appendix. List of Matched Banks

\begin{tabular}{|c|c|c|c|c|}
\hline Year & Bank & Country & Bank & Country \\
\hline 1996 & Altalanos Ertekforgalmi Bank & Hungary & KDB Bank & Hungary \\
\hline 1996 & Hanwha Bank Magyarorszag & Hungary & Konzumbank & Hungary \\
\hline 1996 & Budapest Hiteles Fejleszesi Bank & Hungary & Postabank es Takarekpenztar & Hungary \\
\hline 1996 & Magyar Külkereskedelmi Bank & Hungary & Postabank es Takarekpenztar & Hungary \\
\hline 1996 & Bank Slaski & Poland & Powszechna Kasa Oszczednosci Bank Polski & Poland \\
\hline 1996 & Petrobank & Poland & Bank Gospodarstwa Krajowego & Poland \\
\hline 1997 & Interbanka akciova spolecnost & Czech Republic & Trasta Komercbanka & Latvia \\
\hline 1997 & Kereskedelmi es Hitelbank & Hungary & Postabank es Takarekpenztar & Hungary \\
\hline 1997 & Mezobank & Hungary & Postabank es Takarekpenztar & Hungary \\
\hline 1997 & MeritaNordbanken Latvia & Latvia & Union Banka & Czech Republic \\
\hline 1997 & BRE Bank & Poland & Powszechna Kasa Oszczednosci Bank Polski & Poland \\
\hline 1997 & Bank Rolno-Przemyslowy & Poland & PPA Bank & Poland \\
\hline 1998 & Convest Banka & Croatia & Riadria Banka & Croatia \\
\hline 1998 & Agrobanka Praha & Czech Republic & Bank Wspolpracy Europejskiej & Poland \\
\hline 1998 & HansaPank & Estonia & Banca Romana de Comert Exterior & Romania \\
\hline 1998 & Közép-Europai Nemzetközi Bank & Hungary & Central-European International Bank & Hungary \\
\hline 1998 & Magyar Hitel Bank & Hungary & Central-European International Bank & Hungary \\
\hline 1998 & Latvijas Unibanka & Latvia & Parekss Banka & Latvia \\
\hline 1998 & Bank Podlaski & Poland & PPF Banka & Czech Republic \\
\hline 1999 & First Investment Bank & Bulgaria & Aizkraukles Banka & Latvia \\
\hline 1999 & Commercial Bank Bulgaria Invest & Bulgaria & Pozeska Bank & Croatia \\
\hline 1999 & Transportna Bank & Bulgaria & UAB Medicinos Bankas & Lithuania \\
\hline 1999 & Ceskoslovenska Obchodni Banka & Czech Republic & Central-European International Bank & Hungary \\
\hline 1999 & Eesti Uhispank & Estonia & Maras Banka & Latvia \\
\hline 1999 & Bank Zachodni & Poland & Powszechna Kasa Oszczednosci Bank Polski & Poland \\
\hline
\end{tabular}


Appendix. List of Matched Banks

\begin{tabular}{|c|c|c|c|c|}
\hline Year & Bank & Country & Bank & Country \\
\hline 1999 & Bank Komunalny & Poland & Investbank Bulgaria & Bulgaria \\
\hline 1999 & Bank Przemyslowo-Handlowy & Poland & Konsolidacni Banka Praha & Czech Republic \\
\hline 1999 & Bank Pekao BP & Poland & Powszechna Kasa Oszczednosci Bank Polski & Poland \\
\hline 1999 & Kredyt Bank & Poland & Wielkopolski Bank Kredytowy & Poland \\
\hline 1999 & PP Bank & Poland & Investicni a Postovni Banka & Czech Republic \\
\hline 1999 & Banca Romana Pentru Dezvoltare & Romania & Central-European International Bank & Hungary \\
\hline 2000 & United Bulgarian Bank & Bulgaria & International Orthodox Bank & Bulgaria \\
\hline 2000 & Bulbank & Bulgaria & Romanian Commercial Bank & Romania \\
\hline 2000 & Dalmatinska Banka & Croatia & Postova Banka & Slovakia \\
\hline 2000 & Privredna Banka Zagreb & Croatia & Varazdinska Bank & Croatia \\
\hline 2000 & Ceska Sporitelna & Czech Republic & Romanian Commercial Bank & Romania \\
\hline 2000 & Zivnostenska Banka & Czech Republic & Romanian Commercial Bank & Romania \\
\hline 2000 & Optiva Bank & Estonia & Konzumbank & Hungary \\
\hline 2000 & Prima Banka & Latvia & Dubrovacka Banka & Croatia \\
\hline 2000 & AB Industrijos Banka & Lithuania & Bank Ochrony Srodowiska & Poland \\
\hline 2000 & Lietuvos Vystymo Bankas & Lithuania & StedBanka & Croatia \\
\hline 2000 & Bank Inicjtyw Gospodarczych & Poland & Bribank & Bulgaria \\
\hline 2000 & Bank Wspolpracy Regionalnej & Poland & KDB Bank & Hungary \\
\hline 2000 & Banca de Credit Industrial si Comercial & Romania & Expandia Banka & Czech Republic \\
\hline 2000 & Banca de Credit Pater & Romania & Magyar Takarekszövetkezeti Bank & Hungary \\
\hline 2000 & Polnobanka & Slovakia & Postova Banka & Slovakia \\
\hline 2000 & Prvea Komunalna Banka & Slovakia & Varazdinska Bank & Croatia \\
\hline 2001 & Hebros Bank & Bulgaria & Bank Wspolpracy Europejskiej & Poland \\
\hline 2001 & Splitska Banka & Croatia & Hansabanka & Latvia \\
\hline 2001 & Komercni Banka & Czech Republic & Vilniaus Bankas & Lithuania \\
\hline
\end{tabular}


Appendix. List of Matched Banks (Concluded)

\begin{tabular}{|c|c|c|c|c|}
\hline Year & Bank & Country & Bank & Country \\
\hline 2001 & Paritate Bank & Latvia & Partner Banka & Croatia \\
\hline 2001 & Latvijas Tirdzniecibas Banka & Latvia & Tallinna Aripanga & Estonia \\
\hline 2001 & AB Bankas Hansabankas & Lithuania & Gornoslaski Bank Gospodarczy & Poland \\
\hline 2001 & Bank Swietokrzyski & Poland & Banca Pentru Mica Industrie si Libera & Romania \\
\hline 2001 & Bank Handlowy & Poland & Powszechna Kasa Oszczednosci Bank Polski & Poland \\
\hline 2001 & Demirbank & Romania & Bank Inicjatyw Spoleczno-Ekonomicznych & Poland \\
\hline 2001 & Slovenska Sporitelna & Slovakia & Banca Tiriac & Romania \\
\hline 2001 & Vseobecna Uverova Banka & Slovakia & Bank Inicjatyw Spoleczno-Ekonomicznych & Poland \\
\hline 2002 & Bank Biochim & Bulgaria & Banca Comerciala RoBank & Romania \\
\hline 2002 & Bulgarian Post Bank & Bulgaria & Varazdinska Bank & Hungary \\
\hline 2002 & Lietuvos Zemes Ukio Bankas & Lithuania & Banca Tiriac & Romania \\
\hline 2002 & Cuprum Bank & Poland & Municipal Bank & Bulgaria \\
\hline 2002 & Romanian International Bank & Romania & Libra Bank & Romania \\
\hline 2002 & BAWAG Bank & Slovakia & Getin Bank & Poland \\
\hline 2002 & Investicna a Rozvojova Banka & Slovakia & Orszagos Takarekpenztar es Kereskedelmi & Hungary \\
\hline 2003 & DSK Bank & Bulgaria & UAB Medicinos Bankas & Lithuania \\
\hline 2003 & Agrobanka Praha & Czech Republic & Zemska Bank & Czech Republic \\
\hline 2003 & Inter-Europa Bank & Hungary & Banca Comerciala RoBank & Romania \\
\hline 2003 & Bancpost & Romania & AB Ukio Bankas & Lithuania \\
\hline 2003 & Banca Romaneasca & Romania & Bank Wspolpracy Europejskiej & Poland \\
\hline 2003 & Privatbanka & Slovakia & Bank-Casa de Economii si Consemnatiuni & Romania \\
\hline 2004 & Preatoni Bank & Estonia & Banca Tiriac & Romania \\
\hline 2004 & Sampo Banka & Latvia & VEF Banka & Latvia \\
\hline
\end{tabular}

The table lists banks that were taken over by foreign institutions, their host countries and years of takeover (columns B, C, and A respectively) and their matched banks (column D) and matched banks' countries (column E). 